\title{
Two-Dimensional Covalent Organic Framework Solid Solutions
}

\author{
Rebecca L. Li, Anna Yang, Nathan C. Flanders, Michael T. Yeung, \\ Daylan T. Sheppard, and William R. Dichtel* \\ Department of Chemistry, Northwestern University, \\ 2145 Sheridan Road, Evanston, Illinois 60208, United States
}

\section{Supplementary Information}

\begin{tabular}{|c|}
\hline Correspondence Address \\
\hline Professor William R. Dichtel \\
Department of Chemistry \\
Northwestern University \\
2145 Sheridan Road \\
Evanston, IL 60208 (USA) \\
wdichtel@ northwestern.edu \\
\hline
\end{tabular}

\section{Table of Contents}
A. Materials and Instrumentation
B. Experimental Protocols
C. Additional Characterization
a. TAPB-PDA and TAPB-BDA COF
b. Physical mixtures of TAPB-PDA and TAPB-BDA COFs
c. Pawley refinement
d. Mechanistic studies of solid solution formation
e. $\mathrm{N}_{2}$ isotherm, BET surface area, pore width distribution, and BET plots
S-22
f. Solid state NMR and digestion experiments of COF solid solutions
g. Lattice parameters vs. percent incorporation of BDA 


\section{A. Materials and Instrumentation.}

Reagents were purchased from commercial suppliers and used without additional purification. Dioxane and mesitylene were stored over molecular sieves. 1,3,5-Tris(4-aminophenyl)benzene (TAPB) and 4,4'-biphenyldicarbaldehyde (BDA) were purchased from TCI. Terephthalaldehyde (PDA) was purchased from Sigma Aldrich.

\section{Nuclear Magnetic Resonance Spectroscopy}

${ }^{1} \mathrm{H}$ NMR spectra were collected on Bruker Avance III HD $500 \mathrm{MHz}$ system with a TXO Prodigy probe at $25^{\circ} \mathrm{C}$.

Solid state cross-polarized magic angle spinning (CP-MAS) ${ }^{13} \mathrm{C}$ NMR spectra were recorded on a $400 \mathrm{MHz}$ Bruker Avance III HD NMR spectrometer with a $4 \mathrm{~mm}$ HX probe. The magic angle spinning rate was set to $15000 \mathrm{~Hz}$. The temperature was ambient at $23^{\circ} \mathrm{C}$. The Bruker pulse sequence of cross polarization (cp) was used with normal proton decoupling. Adamantane was used to adjust Hartmann-Hahn matching condition for normal cp experiments.

A typical parameter set was as follows: spectrum frequency $100.524 \mathrm{MHz}$, spectral width 296 $\mathrm{ppm}$, carrier frequency at $100 \mathrm{ppm}$, pre-delay time $5 \mathrm{~s}$, the $90^{\circ}$ pulse width $2.3 \mu \mathrm{s}$ for ${ }^{1} \mathrm{H}$ and 3.5 $\mu$ s for ${ }^{13} \mathrm{C}$, contact time $5 \mathrm{~ms}$, a ramped pulse with 120 Watts used in proton channel during contact time, acquisition time $50 \mathrm{~ms}$, and scan number 256 . Solid state ${ }^{13} \mathrm{C}$ spectra were referenced to an external adamantane peak at $\delta 38.3 \mathrm{ppm}$ and were converted to tetramethylsilane at $\delta 0.0 \mathrm{ppm}$.

\section{X-Ray Diffraction}

A STOE-STADI P powder diffractometer was used to collect powder X-ray diffraction patterns using $\mathrm{CuK} \alpha 1$ radiation. For dried COF powders, samples were secured between acetate foils, mounted in a rotating holder, and measured in transmission geometry. For COF samples in solution, samples were packed in borosilicate capillaries $(1.5 \mathrm{~mm}$ in diameter, wall thickness of $0.01 \mathrm{~mm}$ ), inserted in a pre-aligned capillary stage, and measured in reflection geometry. The instrument uses an asymmetric curved germanium monochromator, silicone strip detector, and line focused $\mathrm{Cu}$ X-ray tube.

Wide-angle X ray scattering (WAXS) patterns were collected at sector 12-ID-D of the Advanced Photon Source at Argonne National Lab with $12.0 \mathrm{keV}$ of beam energy. Each pattern was obtained on a Pilatus 2D detector, averaged, and radially integrated using software available at APS. Dried COF powders were packed into borosilicate capillaries $(1.5 \mathrm{~mm}$ in diameter, wall thickness of $0.01 \mathrm{~mm}$ ) purchased from Charles Supper. 


\section{Gas Adsorption}

Nitrogen adsorption isotherms were collected on a Micromeritics ASAP 2420 accelerated surface area and porosity analyzer. Samples were loaded into a dried analysis tube with a filler rod and a Transeal cap. The samples were evacuated at $25^{\circ} \mathrm{C}$ for 24 hours to degas. The mass of the activated sample was determined by weighing the analysis tube after degassing subtracted by the mass of the dried analysis tube. Nitrogen adsorption isotherms were performed using UHP grade $\mathrm{N}_{2}$, surface areas were determined by the BET model and pore width distributions were determined using the DFT model using the instrument software.

\section{Modeling and Structural Refinement}

Spartan was used to perform geometry optimization to determine the lengths of PDA and BDA. The 6-31G* basis set was employed for all B3LYP.

Materials Studio Version 5.0 was used to simulate powder diffraction patterns of COF structures and perform Pawley refinements. An initial COF structure was built, and the Forcite Module was used to optimize the geometry and energy of the structure with parameters from the Universal Force Field. The Reflex module was used to carry out Pawley refinement with Pseudo-Voigt function to refine the peak profiles. The experimental diffraction patterns were compared with the predicted XRD pattern calculated from the refined unit cell.

\section{Critical Point Dryer}

An automatic critical point dryer Leica EM CPD was used for supercritical point drying. The drying chamber undergoes an initial cooling step to $15^{\circ} \mathrm{C}$ then the chamber is filled with liquid $\mathrm{CO}_{2}$ at a speed of "slow" and a delay time of "120s". Liquid $\mathrm{CO}_{2}$ in the chamber is exchanged for 45 cycles with a speed of " 5 ". Subsequently, the chamber is heated to $40{ }^{\circ} \mathrm{C}$ with a "medium" speed and the pressure was released with a rate of "slow 50\%".

\section{IR}

Infrared spectra were collected with a ZnSe ATR attachment on a Nicolet iS10 FT-IR spectrometer.

\section{Sonication}

Sonication was done using a Branson 3510 ultrasonic cleaner with a power output of $100 \mathrm{~W}$ and a frequency of $42 \mathrm{kHz}$. 


\section{B. Experimental Protocols}

\section{Synthesis of TAPB(PDA 100-xBDA $)$ COF Solid Solutions}

Separate stock solutions of PDA (38.08 mM) and BDA $(38.08 \mathrm{mM})$ in 4:1 Dioxane: Mesitylene were prepared. TAPB $(0.106 \mathrm{mmol}, 37.3 \mathrm{mg})$ was weighed out and combined with the specified volumes of PDA and BDA noted in Table S1 in $20 \mathrm{~mL}$ scintillation vials. The solutions were sonicated for 3 minutes and heat briefly at $70{ }^{\circ} \mathrm{C}$ to ensure dissolution of monomers. DI water $(0.80 \mathrm{~mL})$ was subsequently added followed by glacial acetic acid $(1.20 \mathrm{~mL})$ and the vials were gently swirled to ensure mixing. The vials were transferred to an oven maintained at $70{ }^{\circ} \mathrm{C}$ for 72 hours. After this time period, the COF powders were transferred to a tea bag, washed with $\mathrm{MeOH}$ within a soxhlet extractor for 24 hours, and then subjected to supercritical $\mathrm{CO}_{2}$ drying.

Table S1. Amount of PDA and BDA used to synthesize TAPB-(PDA $100-\mathrm{BDA}$ ) COF solid solutions.

\begin{tabular}{|c|c|c|c|c|c|c|}
\hline & $\begin{array}{l}\text { PDA } \\
(\mathrm{mmol})\end{array}$ & $\begin{array}{l}\text { PDA } \\
(\mathrm{mg})\end{array}$ & $\begin{array}{l}\text { Volume of } \\
\text { PDA stock } \\
\text { solution } \\
(\mathrm{mL})\end{array}$ & $\begin{array}{l}\text { BDA } \\
(\mathrm{mmol})\end{array}$ & BDA (mg) & $\begin{array}{l}\text { Volume of } \\
\text { BDA stock } \\
\text { solution } \\
(\mathrm{mL})\end{array}$ \\
\hline $\begin{array}{l}100 \% \text { PDA, } \\
0 \% \text { BDA }\end{array}$ & 0.159 & 21.35 & 4.18 & N/A & N/A & N/A \\
\hline $\begin{array}{l}95 \% \text { PDA, } \\
5 \% \text { BDA }\end{array}$ & 0.151 & 20.28 & 3.97 & 0.008 & 1.67 & 0.21 \\
\hline $\begin{array}{l}85 \% \text { PDA, } \\
15 \% \text { BDA }\end{array}$ & 0.135 & 18.15 & 3.55 & 0.024 & 5.02 & 0.63 \\
\hline $\begin{array}{l}75 \% \text { PDA, } \\
25 \% \text { BDA }\end{array}$ & 0.119 & 16.01 & 3.14 & 0.040 & 8.37 & 1.05 \\
\hline $\begin{array}{l}66.7 \% \text { PDA, } \\
33.3 \% \mathrm{BDA}\end{array}$ & 0.106 & 14.24 & 2.79 & 0.053 & 11.15 & 1.39 \\
\hline $\begin{array}{l}55 \% \text { PDA, } \\
45 \% \text { BDA }\end{array}$ & 0.088 & 11.74 & 2.30 & 0.072 & 15.06 & 1.88 \\
\hline $\begin{array}{l}50 \% \text { PDA, } \\
50 \% \text { BDA }\end{array}$ & 0.080 & 10.68 & 2.09 & 0.080 & 16.73 & 2.09 \\
\hline $\begin{array}{l}45 \% \text { PDA, } \\
55 \% \text { BDA }\end{array}$ & 0.072 & 9.61 & 1.88 & 0.088 & 18.41 & 2.30 \\
\hline $\begin{array}{l}33.3 \% \text { PDA, } \\
66.7 \% \text { BDA }\end{array}$ & 0.053 & 7.12 & 1.39 & 0.106 & 22.31 & 2.79 \\
\hline
\end{tabular}




\begin{tabular}{|l|l|l|l|l|l|l|}
\hline $\begin{array}{l}\text { 25\% PDA, } \\
75 \% \text { BDA }\end{array}$ & 0.040 & 5.34 & 1.05 & 0.119 & 25.10 & 3.14 \\
\hline $\begin{array}{l}\text { 15\% PDA, } \\
85 \% \text { BDA }\end{array}$ & 0.024 & 3.20 & 0.63 & 0.135 & 28.45 & 3.55 \\
\hline $\begin{array}{l}5 \% \text { PDA, } \\
95 \% \text { BDA }\end{array}$ & 0.008 & 1.07 & 0.21 & 0.151 & 31.79 & 3.97 \\
\hline $\begin{array}{l}\text { 0\% PDA, } \\
100 \% \text { BDA }\end{array}$ & N/A & N/A & N/A & 0.159 & 33.47 & 4.18 \\
\hline
\end{tabular}

\section{Digestion of COF Powders and Determination of Monomer Incorporation Percentages}

$1 \mathrm{mg}$ of COF powder was weighed with a microbalance and transferred into a vial. DMSO- $d_{6}$ $(0.6 \mathrm{~mL})$ and $\mathrm{DCl}(0.1 \mathrm{~mL})$ were added and the mixture was sonicated for 2 minutes to break up COF powder. The vials were heated in an oven held at $90{ }^{\circ} \mathrm{C}$. For $0 \%$ BDA, $5 \%$ BDA, the vials were heated for 5 minutes. For $15-85 \%$ BDA, the vials were heated for 15 minutes and for $95 \%$ and $100 \% \mathrm{BDA}$, the vials were heated for 25 minutes. Aldehyde proton integrals were used to calculate the \%BDA and \%PDA monomers incorporated into the framework.

\section{Determination of Lattice Parameters and Peak Width of Powder X-ray Diffraction Patterns}

WAXS diffraction pattern was fitted with the Pseudo-Voigt function using Origin Pro to determine the peak position and width of the (100), (110) and (200) diffraction peaks. The peak position was converted to d spacing using Bragg's law and lattice parameter was determined from d spacing using the following equation for a hexagonal space group. $\mathrm{d}=$ interplanar spacing; $\mathrm{h}, \mathrm{k}, \mathrm{l}=$ Miller Indices; a, c= lattice parameter

$$
d=\frac{a}{\sqrt{\frac{4}{3}\left(h^{2}+k^{2}+h k\right)+\frac{a^{2}}{c^{2}} l^{2}}}
$$

\section{Physical Mixture of TAPB-PDA and TAPB-BDA COF}

TAPB $(0.53 \mathrm{mmol}, 187.2 \mathrm{mg})$, PDA $(0.80 \mathrm{mmol}, 107.1 \mathrm{mg})$ were weighed out and dissolved in $20.99 \mathrm{~mL}$ of 4:1 Dioxane: Mesitylene. The monomers were sonicated and heated briefly at $70{ }^{\circ} \mathrm{C}$ to dissolve. DI water $(4 \mathrm{~mL})$ and glacial acetic acid $(6 \mathrm{~mL})$ were added, and the COF was heated at $70{ }^{\circ} \mathrm{C}$ in an oven for 72 hours.

TAPB ( $0.53 \mathrm{mmol}, 187.2 \mathrm{mg})$, BDA $(0.80 \mathrm{mmol}, 168.2 \mathrm{mg})$ were weighed out and dissolved in $20.99 \mathrm{~mL}$ of 4:1 Dioxane: Mesitylene. The monomers were sonicated and heated briefly at $70{ }^{\circ} \mathrm{C}$ to dissolve. DI water $(4 \mathrm{~mL})$ and glacial acetic acid $(6 \mathrm{~mL})$ were added, and the COF was heated at $70^{\circ} \mathrm{C}$ in an oven for 72 hours. 
COF powders were transferred into a teabag, washed with $\mathrm{MeOH}$ for 24 hours with a soxhlet extractor at $120{ }^{\circ} \mathrm{C}$, and dried with supercritical $\mathrm{CO}_{2}$. Dried $\mathrm{COF}$ powder were weighed out and ground up with a mortar and pestle to make physical mixture of TAPB-PDA COF and TAPBBDA COF with varying weight percentages.

\section{Monitor the formation of TAPB-(PDA100-xBDA $)$ COF Solid Solution}

Separate stock solutions of PDA $(38.1 \mathrm{mM})$ and BDA $(38.1 \mathrm{mM})$ in 4:1 Dioxane: Mesitylene were prepared. TAPB (54.4 mg) was combined with PDA, and BDA stock solutions according to the amounts noted in Table 2 . and sonicated briefly. $675 \mu \mathrm{L}$ of monomer solution was distributed to 7 different vials and $325 \mu \mathrm{L}$ of $60 \% \mathrm{v} / \mathrm{v}$ glacial acetic acid and $40 \% \mathrm{v} / \mathrm{v}$ DI water mixture was added. The vials were heated at $70^{\circ} \mathrm{C}$ in an oven and after $15 \mathrm{~min}, 30 \mathrm{~min}, 1 \mathrm{~h}, 2 \mathrm{~h}, 4 \mathrm{~h}, 9 \mathrm{~h}$, and $24 \mathrm{~h}$ of heating, one of the vials were removed from the oven. COF powders were packed into borosilicate capillaries and X-ray diffraction was measured in solution with copper radiation source.

Table S2. Amount of PDA and BDA used to synthesize TAPB-(PDA $\left.{ }_{100-x} \mathrm{BDA}_{\mathrm{x}}\right)$ COF solid solutions and monitor their formation as a function of time.

\begin{tabular}{|l|l|l|l|l|l|l|}
\hline & $\begin{array}{l}\text { PDA } \\
(\mathrm{mmol})\end{array}$ & $\begin{array}{l}\text { PDA } \\
(\mathrm{mg})\end{array}$ & $\begin{array}{l}\text { Volume of } \\
\text { PDA stock } \\
\text { solution } \\
(\mathrm{mL})\end{array}$ & $\begin{array}{l}\text { BDA } \\
(\mathrm{mmol})\end{array}$ & BDA (mg) & $\begin{array}{l}\text { Volume of } \\
\text { BDA stock } \\
\text { solution } \\
(\mathrm{mL})\end{array}$ \\
\hline $\begin{array}{l}100 \% \text { PDA, } \\
0 \% \text { BDA }\end{array}$ & 0.232 & 31.14 & 6.10 & N/A & N/A & N/A \\
\hline $\begin{array}{l}75 \% \text { PDA, } \\
25 \% \text { BDA }\end{array}$ & 0.174 & 23.36 & 4.57 & 0.058 & 12.20 & 1.52 \\
\hline $\begin{array}{l}55 \% \text { PDA, } \\
45 \% \text { BDA }\end{array}$ & 0.128 & 17.13 & 3.35 & 0.104 & 21.97 & 2.74 \\
\hline $\begin{array}{l}45 \% \text { PDA, } \\
55 \% \text { BDA }\end{array}$ & 0.104 & 14.02 & 2.74 & 0.128 & 26.85 & 3.35 \\
\hline $\begin{array}{l}25 \% \text { PDA, } \\
75 \% \text { BDA }\end{array}$ & 0.058 & 7.79 & 1.52 & 0.174 & 36.61 & 4.57 \\
\hline $\begin{array}{l}0 \% \text { PDA, } \\
100 \% \text { BDA }\end{array}$ & N/A & N/A & N/A & 0.232 & 48.82 & 6.10 \\
\hline
\end{tabular}




\section{Addition of TAPB-BDA COF Reagents Post Synthesis of TAPB-PDA COF}

A stock solution of TAPB (25.39 mM) and PDA (38.04 mM) in 4:1 Dioxane: Mesitylene was prepared. Different volumes of TAPB-PDA stock solution were combined with DI water and acetic acid according to the amounts noted in Table 3 below. The vials were heated in a $70{ }^{\circ} \mathrm{C}$ oven for 72 hours. Subsequently, the vials were removed, cooled to room temperature and different volumes of TAPB-BDA stock solution (TAPB (25.39 mM) and BDA (38.11 mM)) were added according to the volumes noted in Table 4 , along with DI water and acetic acid. The vials were heated again in the oven at $70^{\circ} \mathrm{C}$ for an additional 72 hours. The final COF product was transferred to a tea bag and washed with $\mathrm{MeOH}$ using a soxhlet extractor for $24 \mathrm{~h}$. The COFs were dried with supercritical $\mathrm{CO}_{2}$ and ground up with a mortar and pestle before characterization. COFs made with 100\% PDA and 100\% BDA were reacted for only 72 hours to serve as a control.

Table S3. Amount of TAPB and PDA used to synthesize a series of TAPB-PDA COF with different volumes.

\begin{tabular}{|l|l|l|l|l|l|}
\hline & $\begin{array}{l}\text { TAPB, PDA } \\
(\mathrm{mmol})\end{array}$ & $\begin{array}{l}\text { TAPB, PDA } \\
(\mathrm{mg})\end{array}$ & $\begin{array}{l}\text { Volume of } \\
\text { TAPB + PDA } \\
\text { stock solution } \\
(\mathrm{mL})\end{array}$ & $\begin{array}{l}\text { DI water } \\
(\mathrm{mL})\end{array}$ & $\begin{array}{l}\text { Acetic acid } \\
(\mathrm{mL})\end{array}$ \\
\hline $\begin{array}{l}\text { 100\% PDA, 0\% } \\
\text { BDA }\end{array}$ & $0.106,0.159$ & $37.30,21.35$ & 4.18 & 0.8 & 1.20 \\
\hline $\begin{array}{l}\text { 95\% PDA, 5\% } \\
\text { BDA }\end{array}$ & $0.101,0.151$ & $35.43,20.28$ & 3.97 & 0.76 & 1.14 \\
\hline $\begin{array}{l}85 \% \text { PDA, 15\% } \\
\text { BDA }\end{array}$ & $0.090,0.135$ & $31.70,18.15$ & 3.55 & 0.68 & 1.02 \\
\hline $\begin{array}{l}75 \% \text { PDA, 25\% } \\
\text { BDA }\end{array}$ & $0.080,0.119$ & $27.97,16.01$ & 3.13 & 0.60 & 0.9 \\
\hline $\begin{array}{l}\text { 66.7\% PDA, } \\
33.3 \% \text { BDA }\end{array}$ & $0.071,0.106$ & $24.87,14.24$ & 2.78 & 0.54 \\
\hline $\begin{array}{l}55 \% \text { PDA, 45\% } \\
\text { BDA }\end{array}$ & $0.058,0.088$ & $20.51,11.74$ & 2.30 & 0.46 & 0.60 \\
\hline $\begin{array}{l}50 \% \text { PDA, 50\% } \\
\text { BDA }\end{array}$ & $0.053,0.080$ & $18.65,10.68$ & 2.09 & 0.44 & 0.63 \\
\hline $\begin{array}{l}45 \% \text { PDA, 55\% } \\
\text { BDA }\end{array}$ & $0.048,0.072$ & $16.78,9.61$ & 1.88 & & 0.36 \\
\hline
\end{tabular}




\begin{tabular}{|l|l|l|l|l|l|}
\hline $\begin{array}{l}33.3 \% \text { PDA, } \\
66.7 \% \text { BDA }\end{array}$ & $0.035,0.053$ & $12.43,7.12$ & 1.39 & 0.27 & 0.40 \\
\hline $\begin{array}{l}25 \% \text { PDA, 75\% } \\
\text { BDA }\end{array}$ & $0.027,0.040$ & $9.32,5.34$ & 1.04 & 0.20 & 0.30 \\
\hline $\begin{array}{l}15 \% \text { PDA, 85\% } \\
\text { BDA }\end{array}$ & $0.016,0.024$ & $5.59,3.20$ & 0.63 & 0.12 & 0.18 \\
\hline $\begin{array}{l}5 \% \text { PDA, 95\% } \\
\text { BDA }\end{array}$ & $0.005,0.008$ & $1.86,1.07$ & 0.21 & 0.04 & 0.06 \\
\hline $\begin{array}{l}\text { 0\% PDA, 100\% } \\
\text { BDA }\end{array}$ & N/A & N/A & N/A & N/A & N/A \\
\hline
\end{tabular}

Table S4. Amount of TAPB and BDA used to synthesize a series of TAPB-BDA COF with different volumes.

\begin{tabular}{|l|l|l|l|l|l|}
\hline & $\begin{array}{l}\text { TAPB, PDA } \\
(\mathrm{mmol})\end{array}$ & $\begin{array}{l}\text { TAPB, BDA } \\
(\mathrm{mg})\end{array}$ & $\begin{array}{l}\text { Volume of } \\
\text { TAPB }+ \text { BDA } \\
\text { stock solution } \\
(\mathrm{mL})\end{array}$ & $\begin{array}{l}\text { DI water } \\
(\mathrm{mL})\end{array}$ & $\begin{array}{l}\text { Acetic acid } \\
(\mathrm{mL})\end{array}$ \\
\hline $\begin{array}{l}100 \% \text { PDA, 0\% } \\
\text { BDA }\end{array}$ & N/A & N/A & N/A & N/A & N/A \\
\hline $\begin{array}{l}\text { 95\% PDA, 5\% } \\
\text { BDA }\end{array}$ & $0.005,0.008$ & $1.86,1.67$ & 0.21 & 0.04 & 0.06 \\
\hline $\begin{array}{l}85 \% \text { PDA, 15\% } \\
\text { BDA }\end{array}$ & $0.016,0.024$ & $5.59,5.02$ & 0.63 & 0.12 & 0.18 \\
\hline $\begin{array}{l}75 \% \text { PDA, 25\% } \\
\text { BDA }\end{array}$ & $0.027,0.040$ & $9.32,8.37$ & 1.04 & 0.2 & 0.3 \\
\hline $\begin{array}{l}\text { 66.7\% PDA, } \\
33.3 \% \text { BDA }\end{array}$ & $0.035,0.053$ & $12.43,11.15$ & 1.39 & 0.27 & 0.4 \\
\hline $\begin{array}{l}55 \% \text { PDA, 45\% } \\
\text { BDA }\end{array}$ & $0.048,0.072$ & $16.78,15.06$ & 1.88 & 0.36 & 0.54 \\
\hline $\begin{array}{l}50 \% \text { PDA, 50\% } \\
\text { BDA }\end{array}$ & $0.053,0.080$ & $18.65,16.73$ & 2.09 & 0.4 & 0.6 \\
\hline $\begin{array}{l}45 \% \text { PDA, 55\% } \\
\text { BDA }\end{array}$ & $0.058,0.088$ & $20.51,18.41$ & 2.3 & 0.44 & 0.66 \\
\hline
\end{tabular}




\begin{tabular}{|l|l|l|l|l|l|}
\hline $\begin{array}{l}33.3 \% \text { PDA, } \\
66.7 \% \text { BDA }\end{array}$ & $0.071,0.106$ & $24.87,22.31$ & 2.78 & 0.53 & 0.8 \\
\hline $\begin{array}{l}\text { 25\% PDA, 75\% } \\
\text { BDA }\end{array}$ & $0.080,0.119$ & $27.97,25.10$ & 3.13 & 0.6 & 0.9 \\
\hline $\begin{array}{l}\text { 15\% PDA, 85\% } \\
\text { BDA }\end{array}$ & $0.090,0.135$ & $31.70,28.45$ & 3.55 & 0.68 & 1.02 \\
\hline $\begin{array}{l}\text { 5\% PDA, 95\% } \\
\text { BDA }\end{array}$ & $0.101,0.151$ & $35.43,31.79$ & 3.97 & 0.76 & 1.14 \\
\hline $\begin{array}{l}\text { 0\% PDA, } 100 \% \\
\text { BDA }\end{array}$ & $0.106,0.159$ & $37.30,33.47$ & 4.18 & 0.8 & 1.2 \\
\hline
\end{tabular}




\section{Additional Characterization}

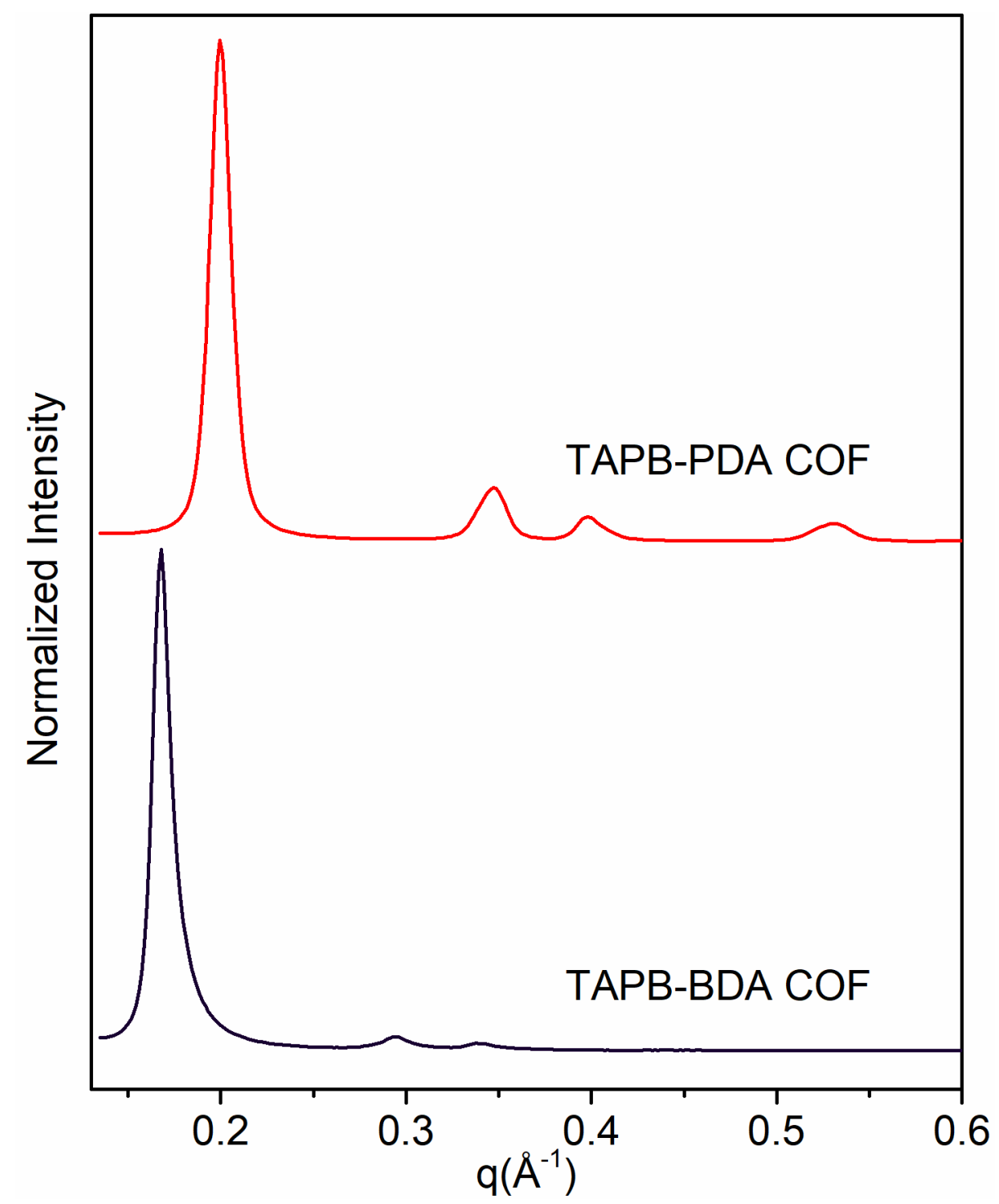

Figure S1. WAXS diffraction pattern of TAPB-PDA and TAPB-BDA COF. 


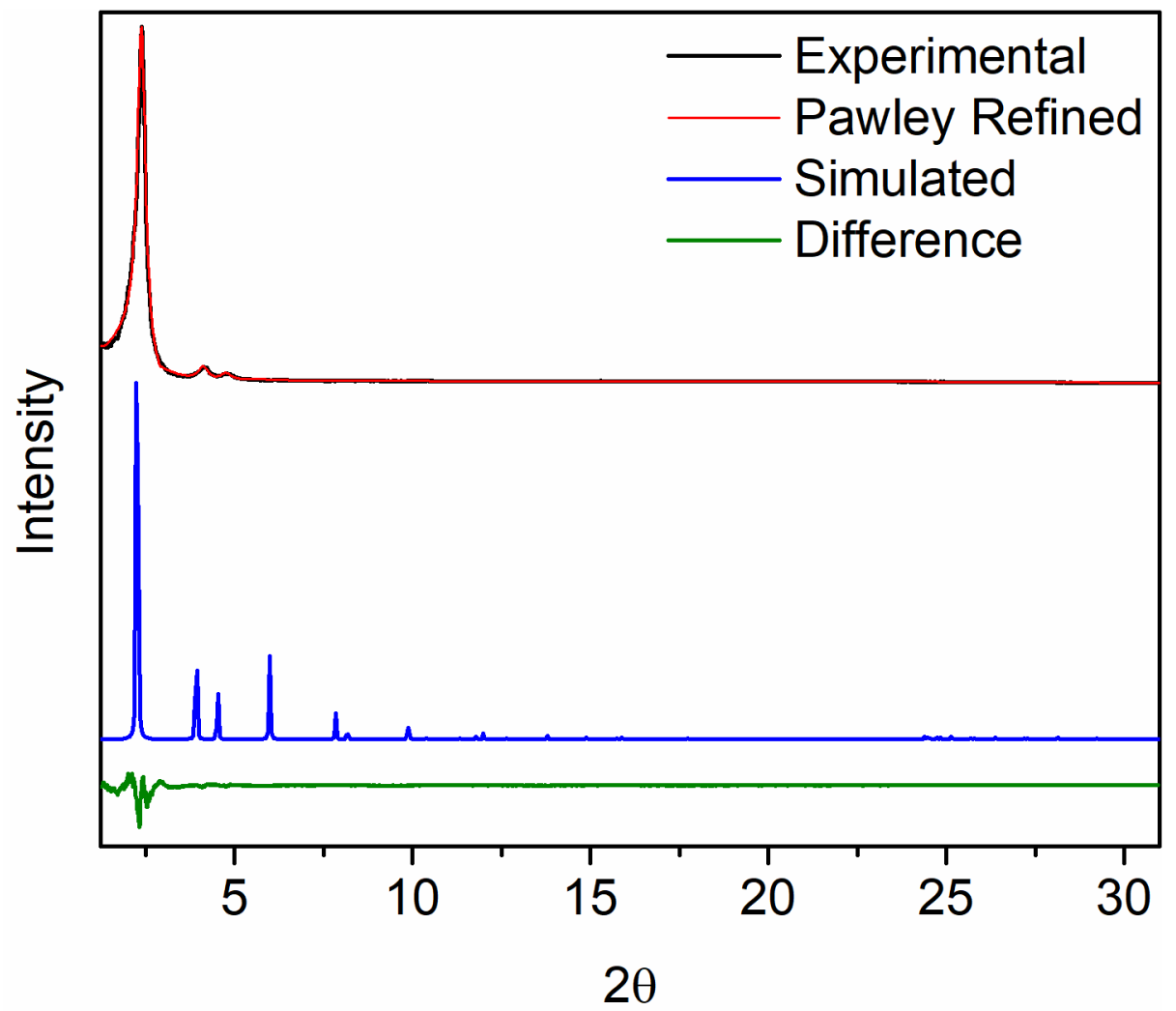

Figure S2. Experimental PXRD pattern for COF synthesized from TAPB and BDA compared with Pawley refined PXRD pattern (Red), simulated PXRD pattern (Blue), and the difference pattern between the experimental and Pawley refined PXRD pattern (Green).

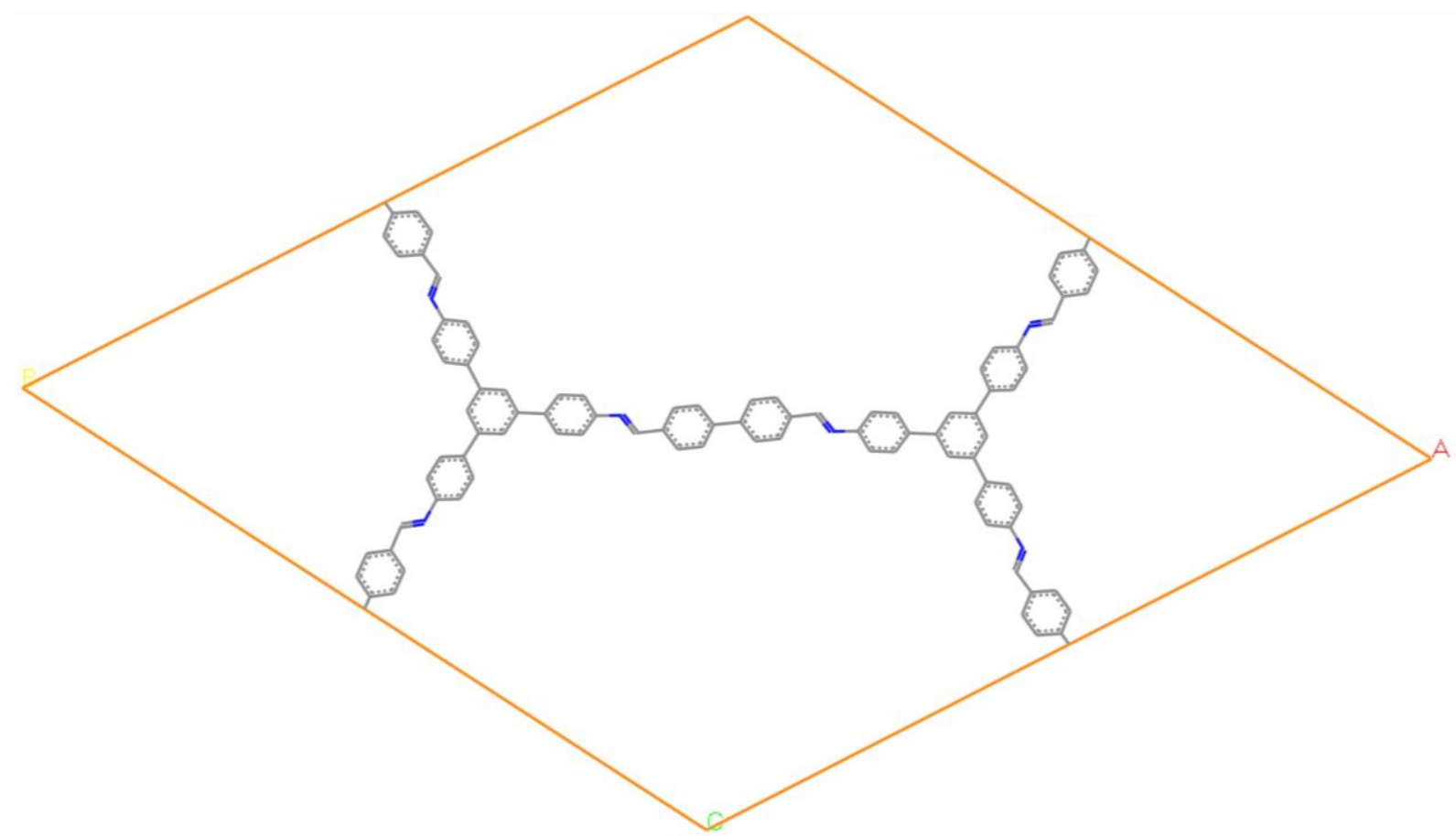

Figure S3. Structure of TAPB-BDA (100\%) COF after Pawley refinement. 


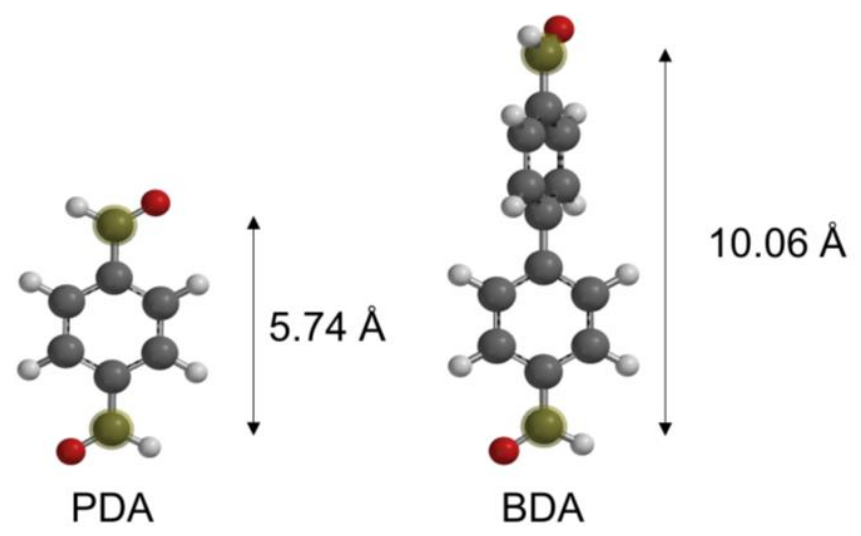

Figure S4. Length of each linker calculated from $\mathrm{C}_{\mathrm{C}=\mathrm{O}}$ to $\mathrm{C}_{\mathrm{C}=\mathrm{O}}$ 


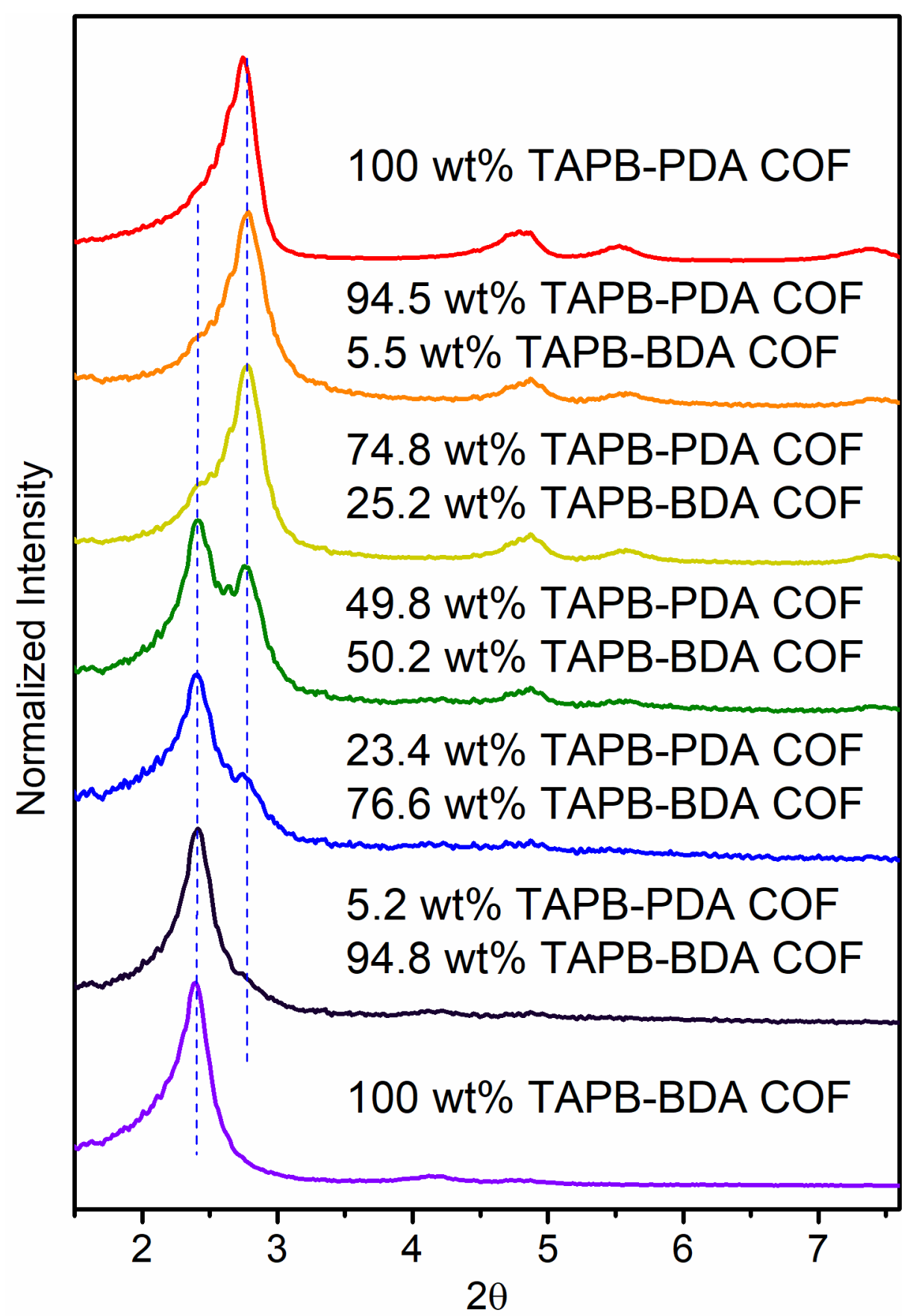

Figure S5. PXRD of physical mixtures of TAPB-PDA and TAPB-BDA COFs made by grinding different weight percentages of TAPB-PDA and TAPB-BDA COFs together with a mortar and pestle. The COFs were independently synthesized, purified, and weighed. 


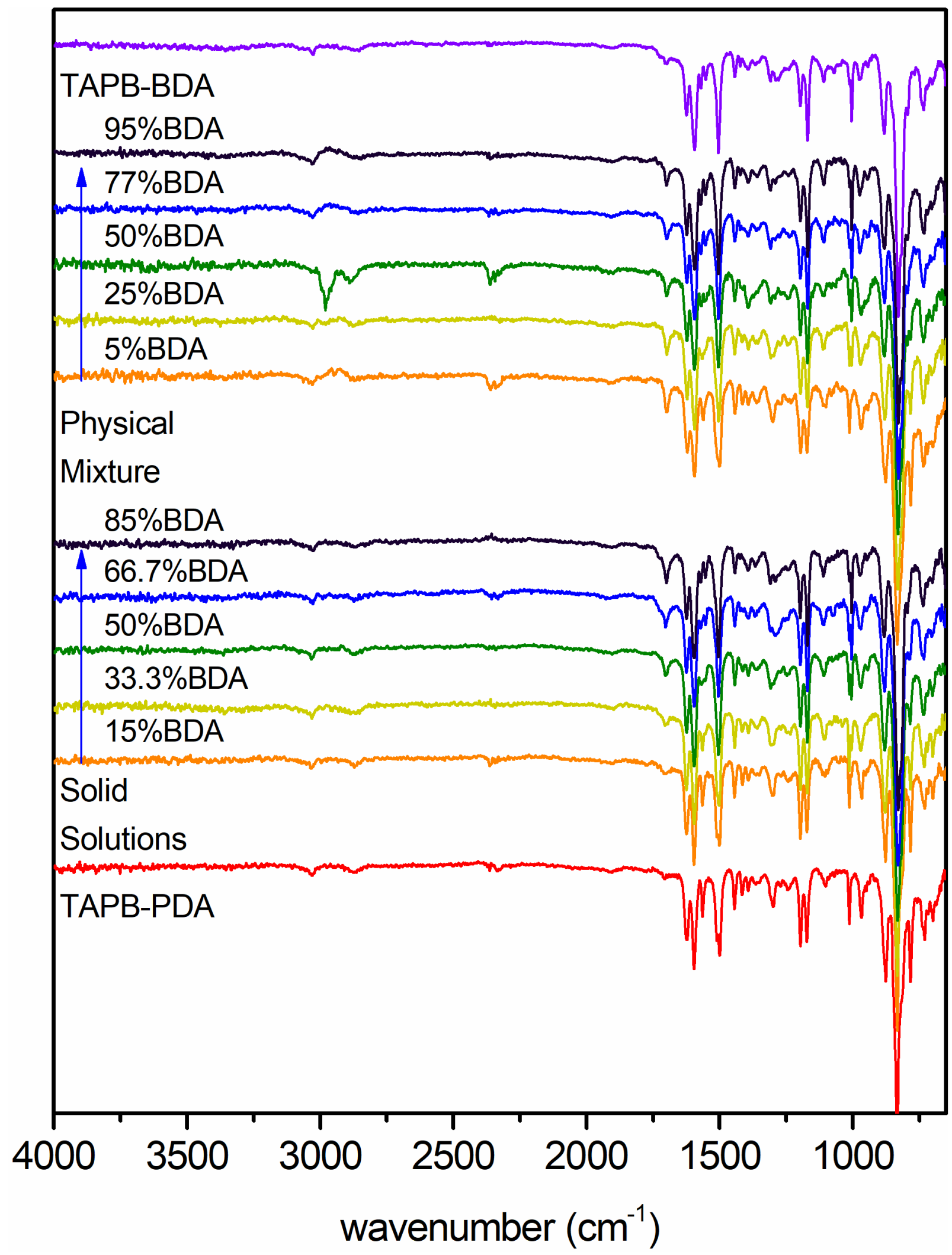

Figure S6. FT-IR spectra $\left(4000-650 \mathrm{~cm}^{-1}\right)$ of TAPB-(PDA $\left.100-\mathrm{BD} \mathrm{B}_{\mathrm{x}}\right) \mathrm{COF}$ solid solutions compared with physical mixtures of TAPB-PDA and TAPB-BDA COFs. 


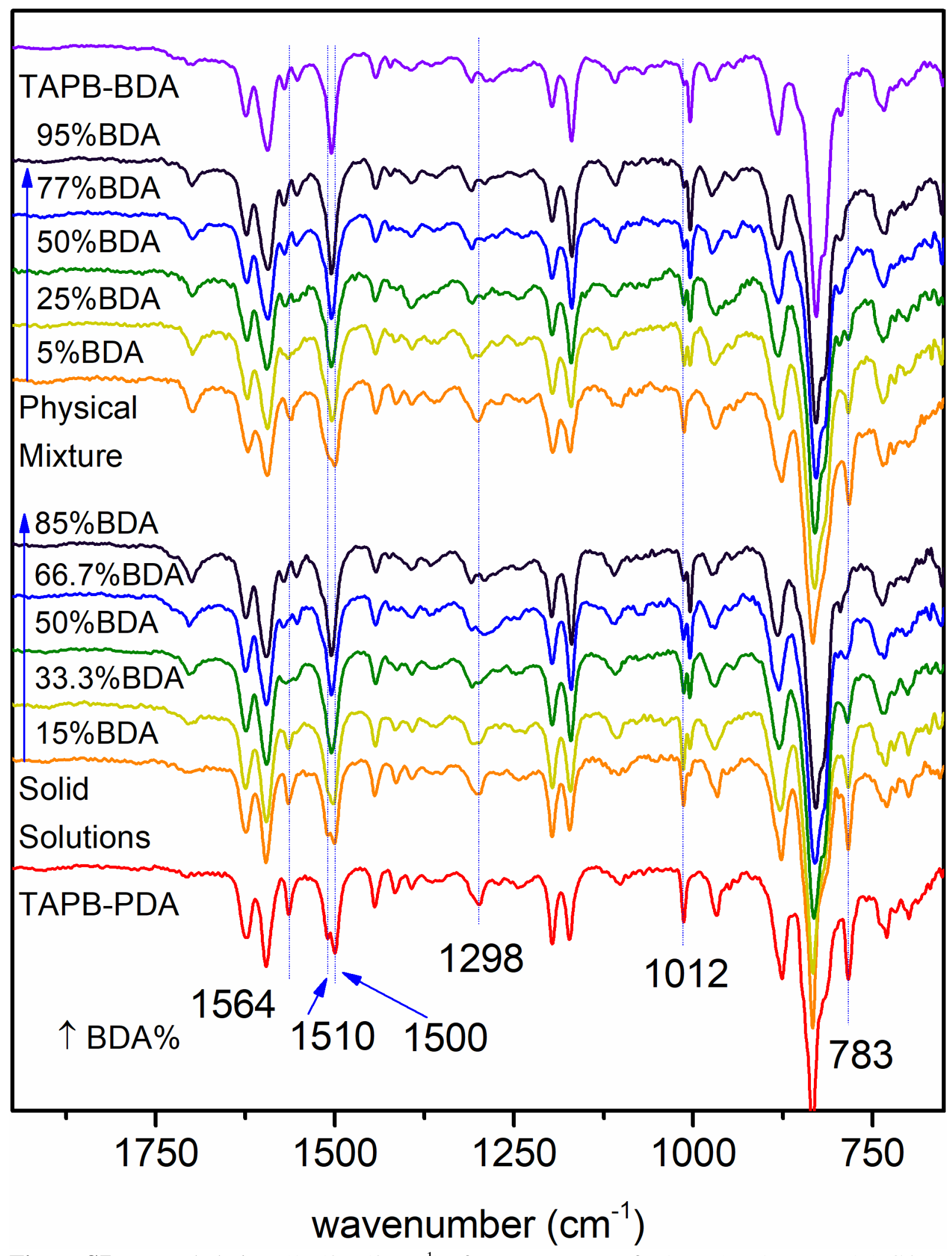

Figure S7. Expanded view $\left(1950-650 \mathrm{~cm}^{-1}\right)$ of FT-IR spectra of TAPB-(PDA $100-\mathrm{BDDA}$ ) COF solid solutions compared with physical mixtures of TAPB-PDA and TAPB-BDA COFs. 

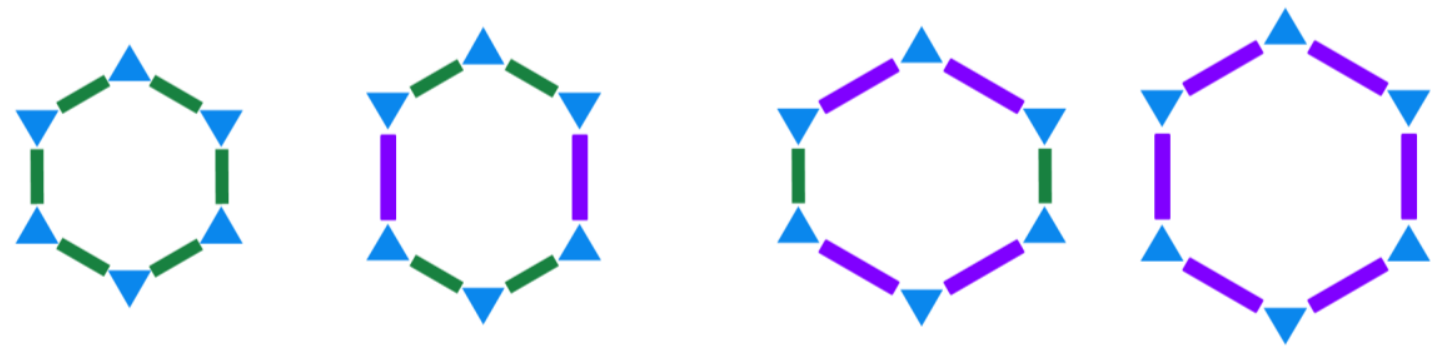

$100 \%$ PDA $\quad 33 \%$ BDA, $66 \%$ PDA $\quad 66 \%$ BDA, 33\% PDA $\quad 100 \%$ BDA

Figure S8. Schematic representation of periodic structure that can theoretically form from a mixture of PDA and BDA when molar ratio is controlled at 1:2 or 2:1. 


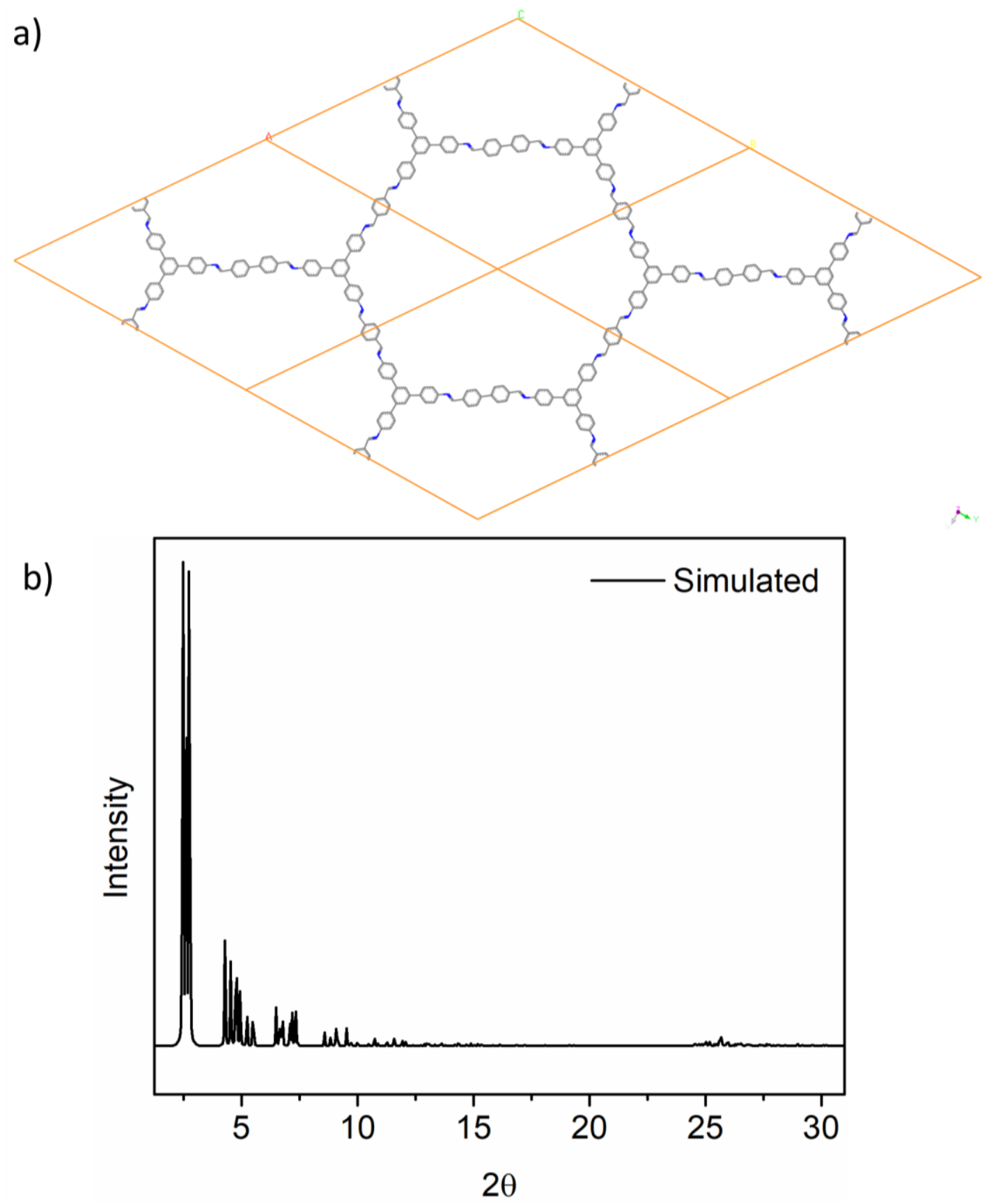

Figure S9. a) Theoretical structure of TAPB-PDA (66.67\%)-BDA (33.3\%) COF if monomers are arranged in a periodic structure after geometry and energy optimization and the corresponding b) simulated PXRD pattern. 


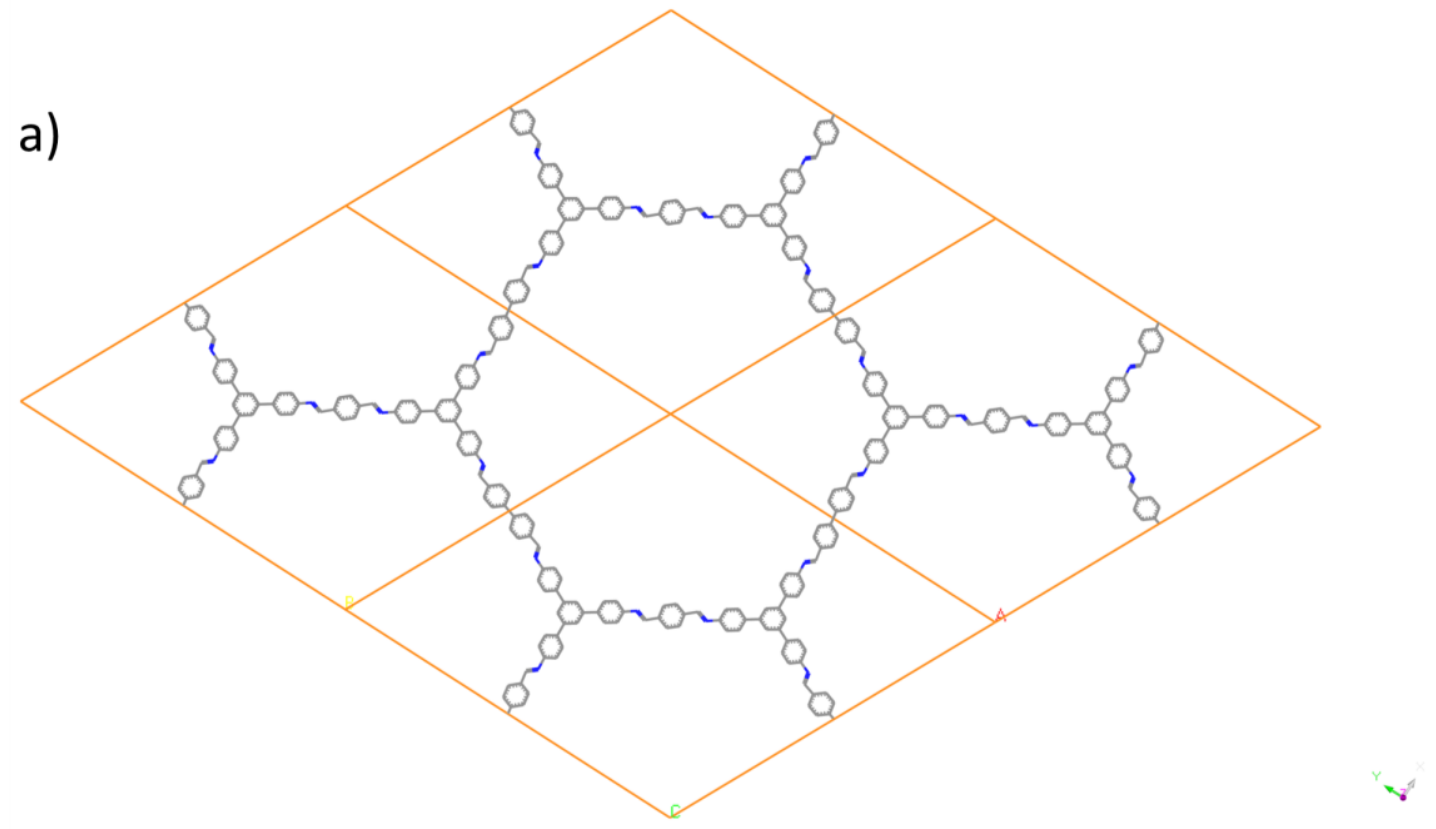

b)

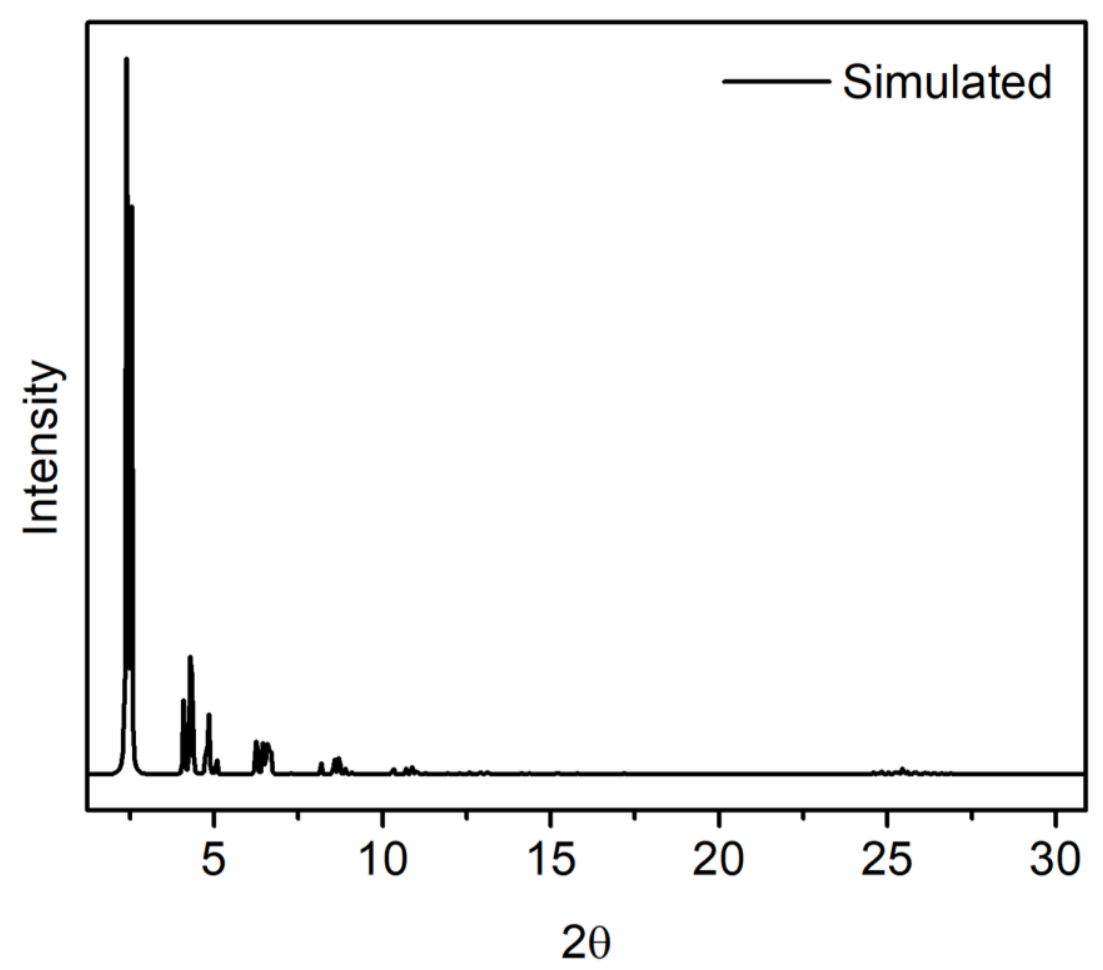

Figure S10. a) Theoretical structure of TAPB-PDA (33.33\%)-BDA (66.67\%) COF if monomers are arranged in a periodic structure after geometry and energy optimization and the corresponding b) simulated PXRD pattern. 


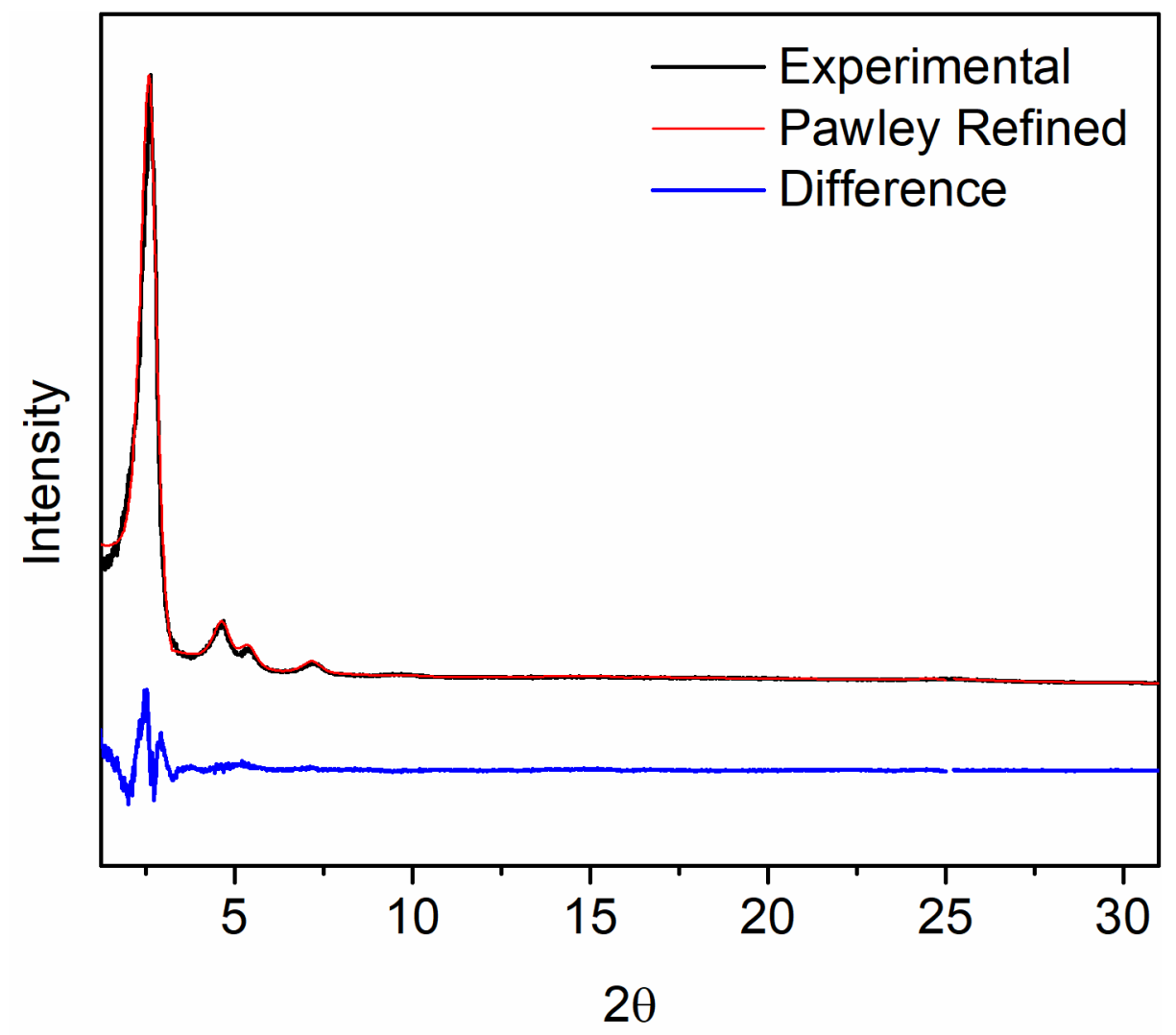

Figure S11. Experimental PXRD pattern of TAPB-PDA (66.67\%)-BDA (33.33\%) COF compared with Pawley refined PXRD pattern (Red), and the difference pattern between the experimental and Pawley refined PXRD pattern (Blue). 


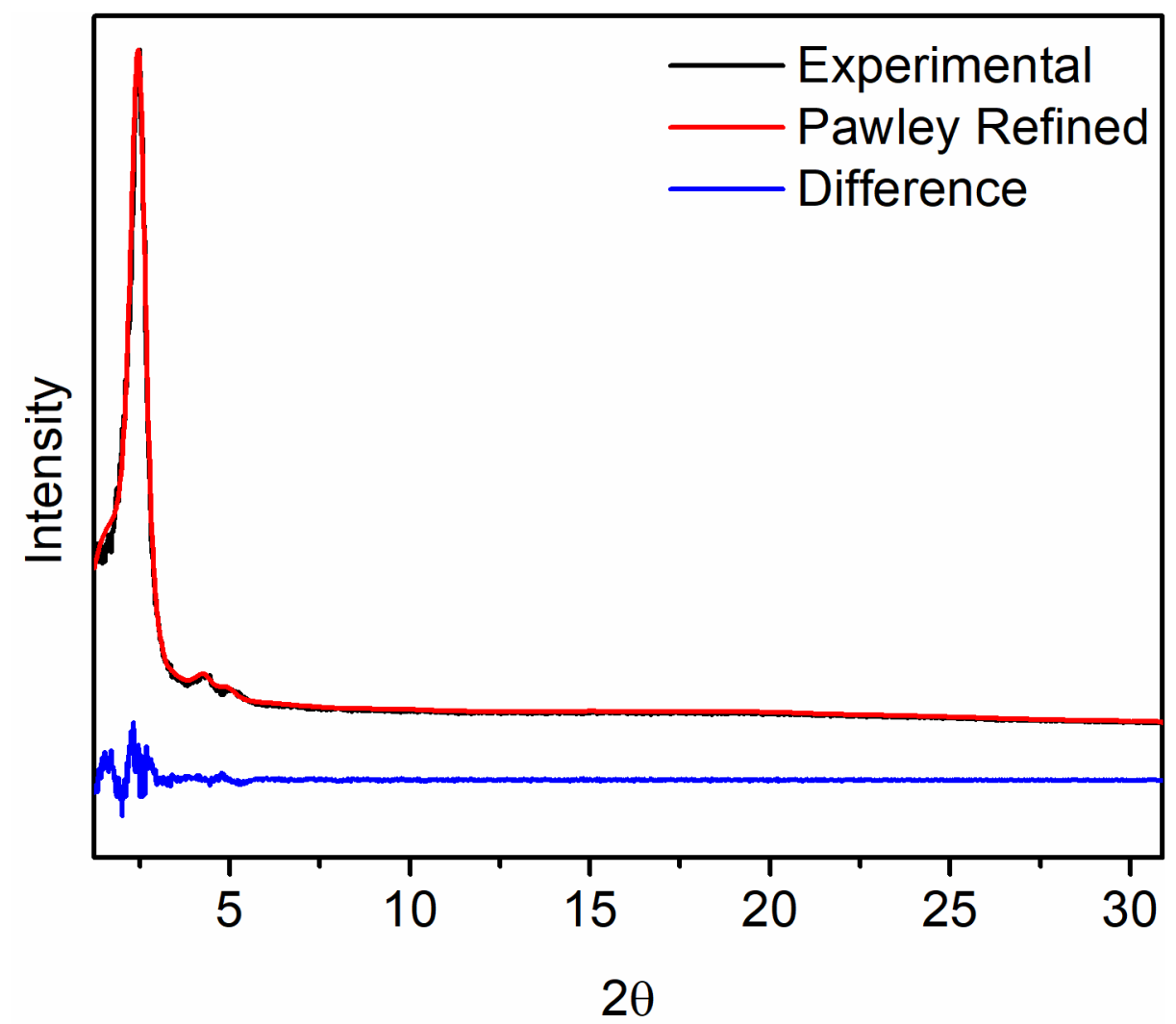

Figure S12. Experimental PXRD pattern of TAPB-PDA (33.33\%)-BDA (66.67\%) COF compared with Pawley refined PXRD pattern (Red), and the difference pattern between the experimental and Pawley refined PXRD pattern (Blue). 

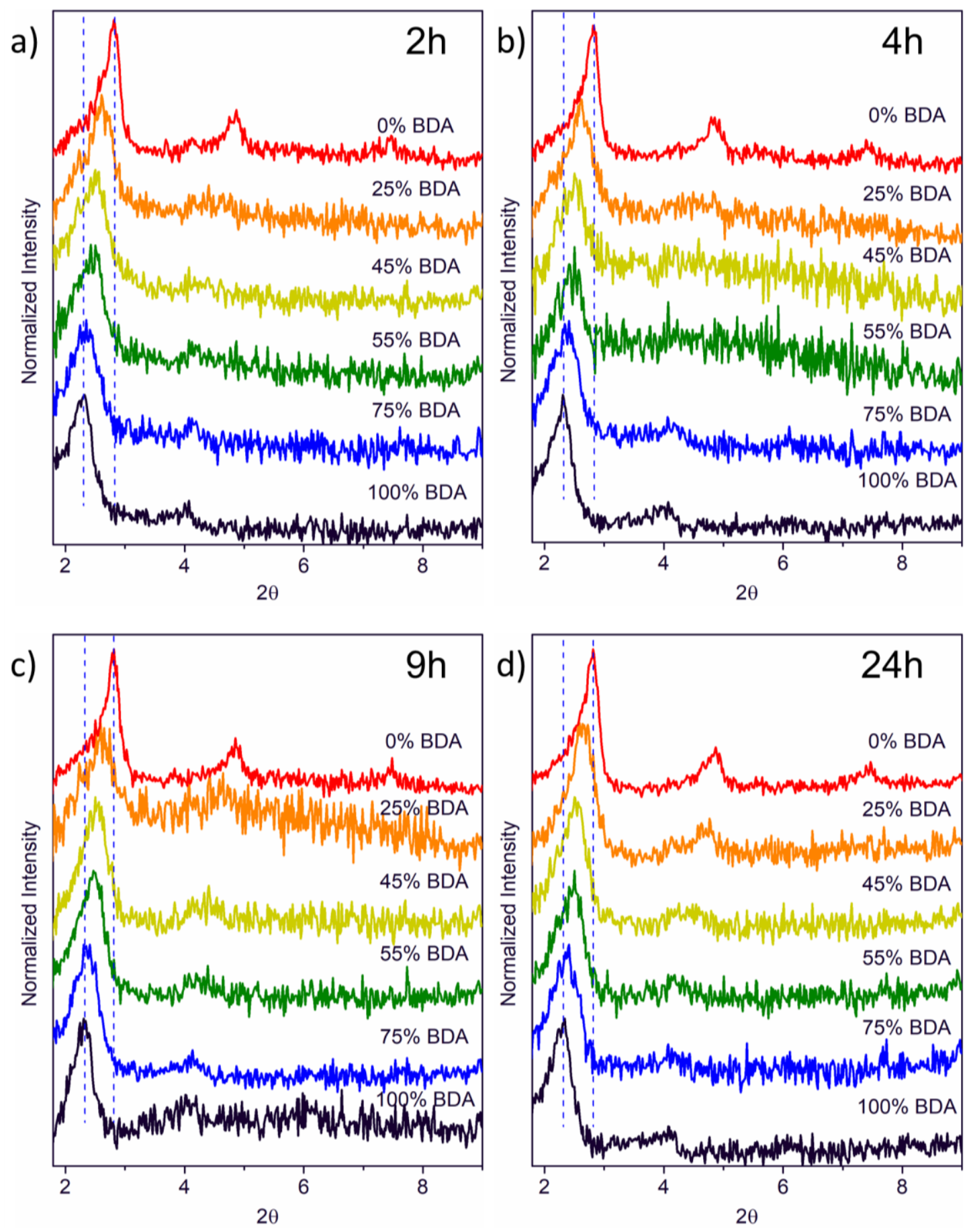

Figure S13. In-solution PXRD of COFs synthesized with varying \% of BDA after reaction for a) $2 \mathrm{~h}, \mathrm{~b}) 4 \mathrm{~h}, \mathrm{c}) 9 \mathrm{~h}$, and d) $24 \mathrm{~h}$ at $70^{\circ} \mathrm{C}$ packed in capillaries. 




Figure S14. PXRD of COFs formed from the sequential addition of reagents to form different $\%$ of TAPB-BDA COF post polymerization of TAPB-PDA COF for 3 days at $70^{\circ} \mathrm{C}$. 


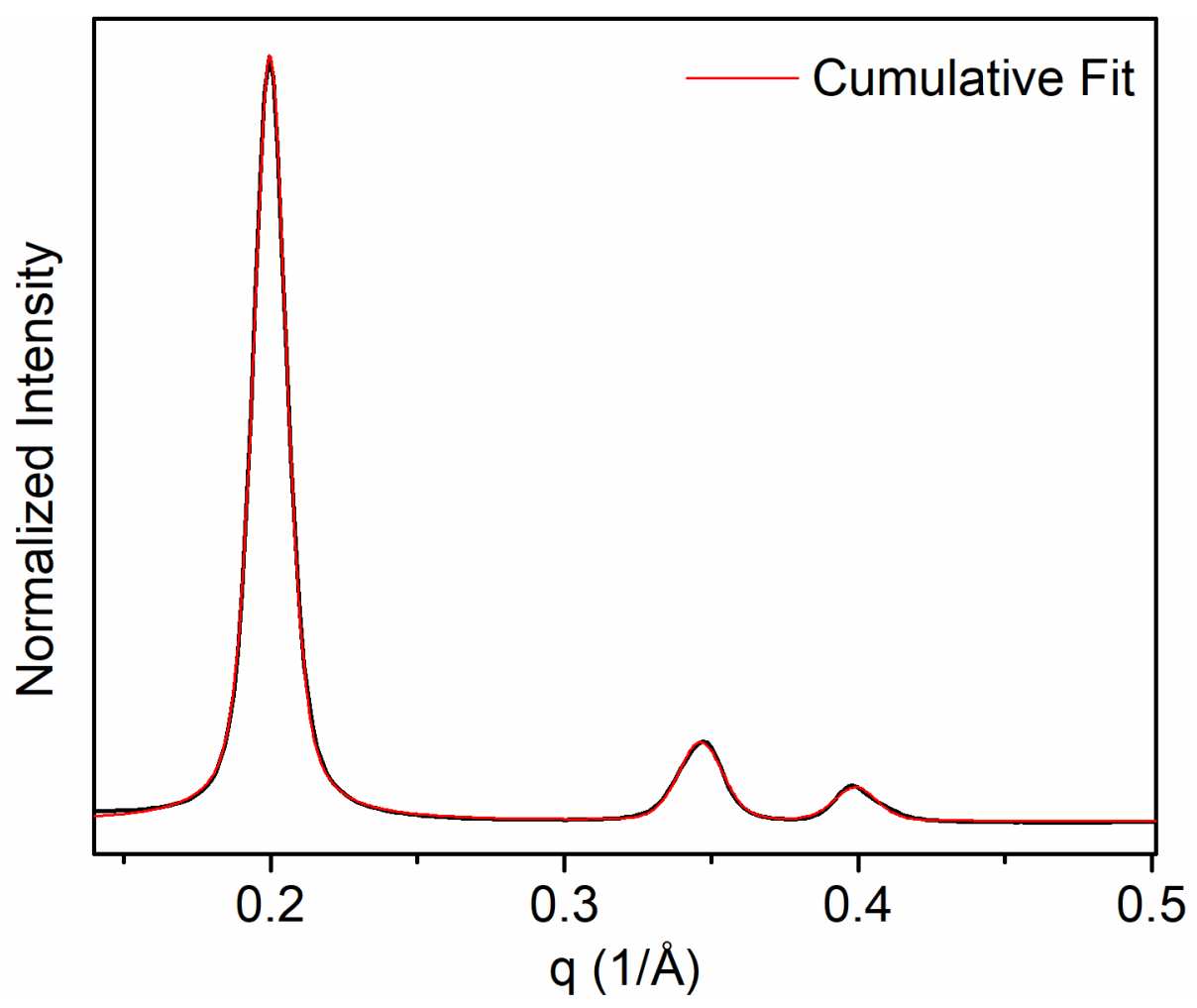

Figure S15. Representative fit of WAXS diffraction pattern with a pseudo-Voigt function to determine the peak position and FWHM of (100), (110) and (200) diffraction peaks.

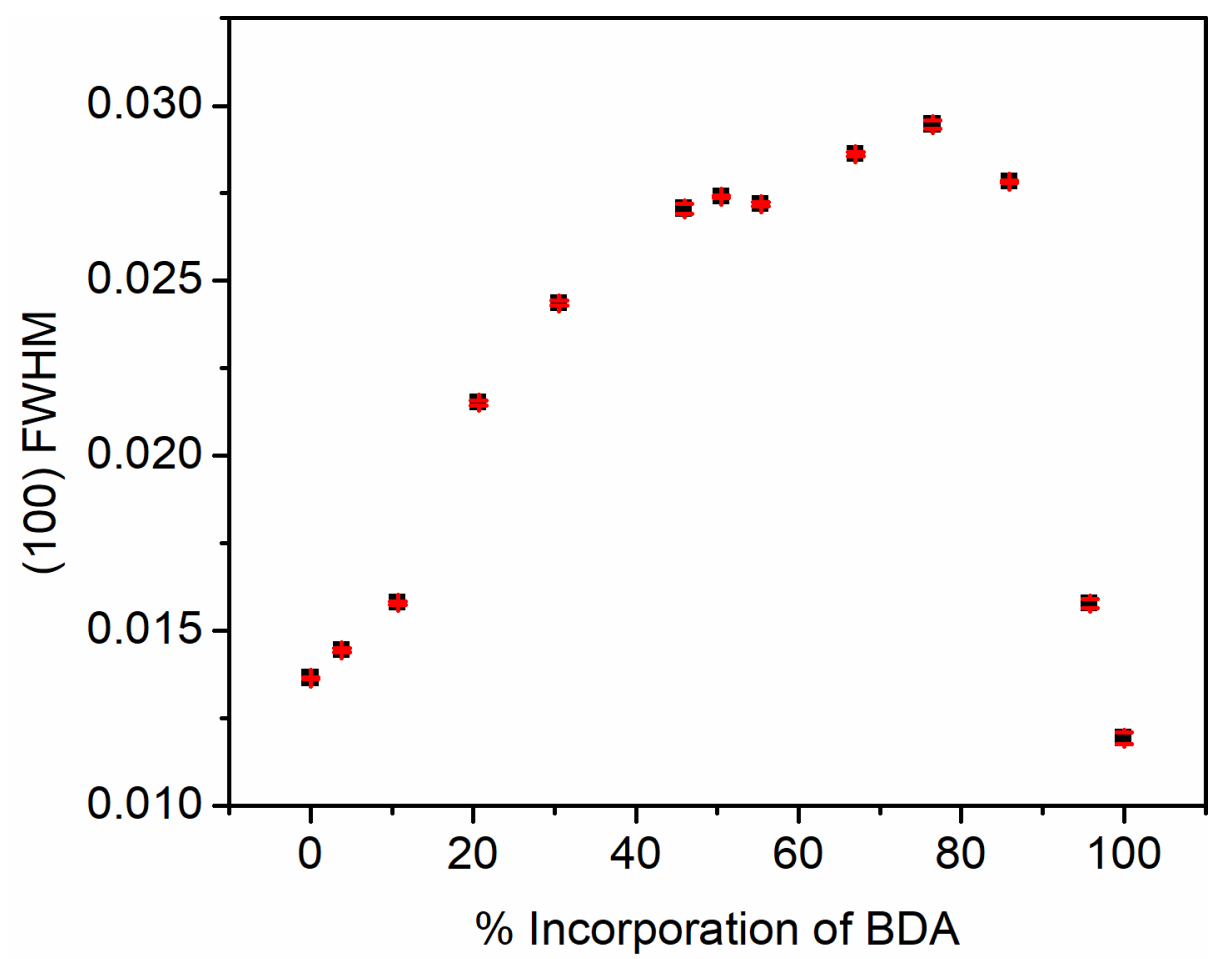

Figure S16. FWHM of the (100) peak of TAPB-(PDA $\left.100-x \mathrm{BDA}_{\mathrm{x}}\right) \mathrm{COF}$ solid solutions determined from pseudo-Voigt fitting as a function of \% incorporation of BDA. 

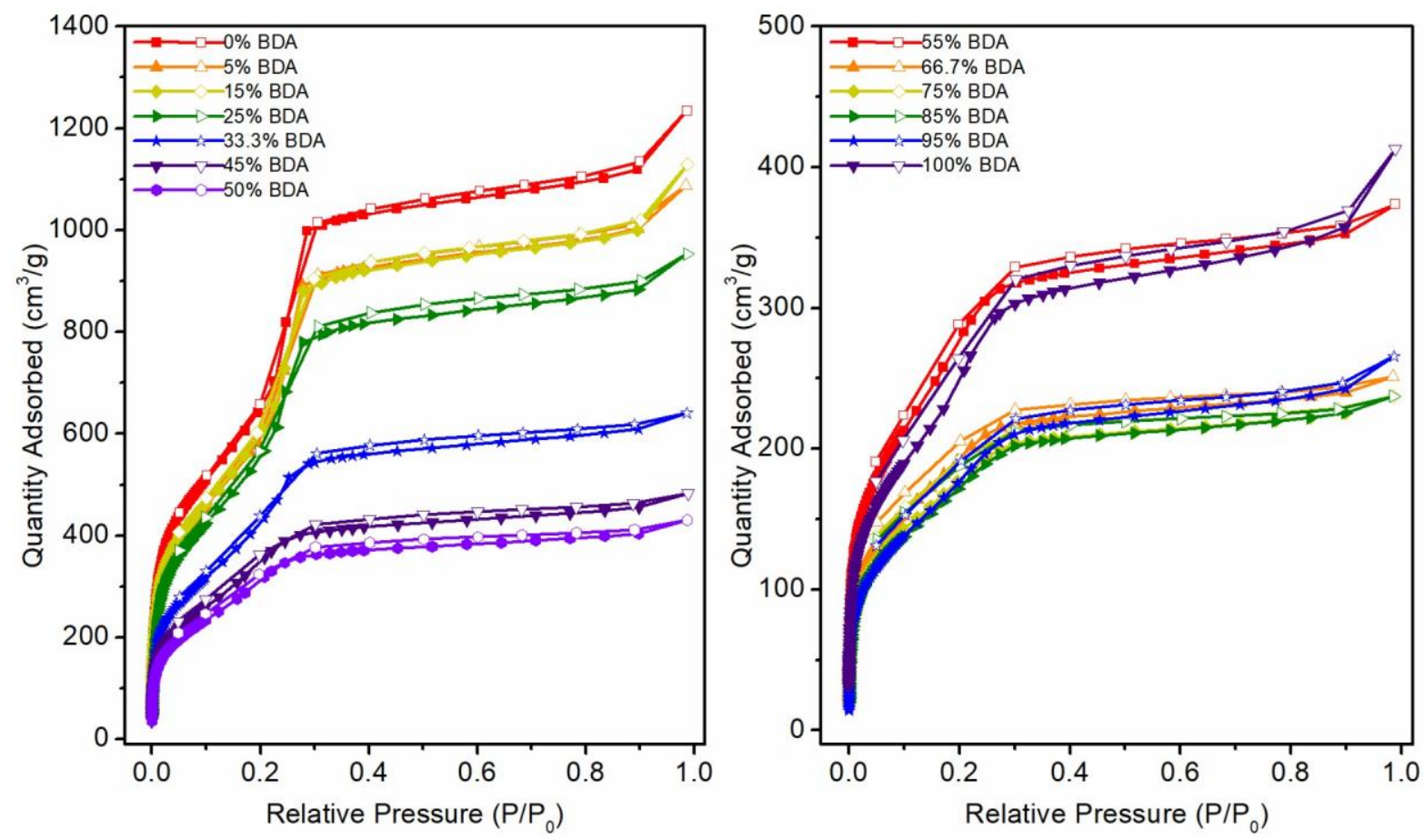

Figure S17. Nitrogen adsorption isotherms of TAPB-(PDA $\left.100-\mathrm{x} \mathrm{BDA}_{\mathrm{x}}\right) \mathrm{COF}$ solid solutions synthesized with varying percentages of BDA and PDA linkers.

\begin{tabular}{|c|c|}
\hline$\%$ BDA & Surface Area $\left(\mathrm{m}^{2} / \mathrm{g}\right)$ \\
\hline $0 \%$ BDA & 2230 \\
\hline $5 \%$ BDA & 2010 \\
\hline $15 \%$ BDA & 2050 \\
\hline $25 \%$ BDA & 1870 \\
\hline $33.3 \%$ BDA & 1440 \\
\hline $45 \%$ BDA & 1200 \\
\hline $50 \%$ BDA & 1060 \\
\hline $55 \%$ BDA & 960 \\
\hline $66.7 \%$ BDA & 700 \\
\hline $75 \%$ BDA & 670 \\
\hline $85 \%$ BDA & 630 \\
\hline $95 \%$ BDA & 630 \\
\hline $100 \%$ BDA & 860 \\
\hline
\end{tabular}

Table S5. Surface area values of TAPB-(PDA $\left.100-\mathrm{BDA} \mathrm{A}_{\mathrm{x}}\right)$ COF solid solutions synthesized with varying percentages of BDA and PDA linkers. 


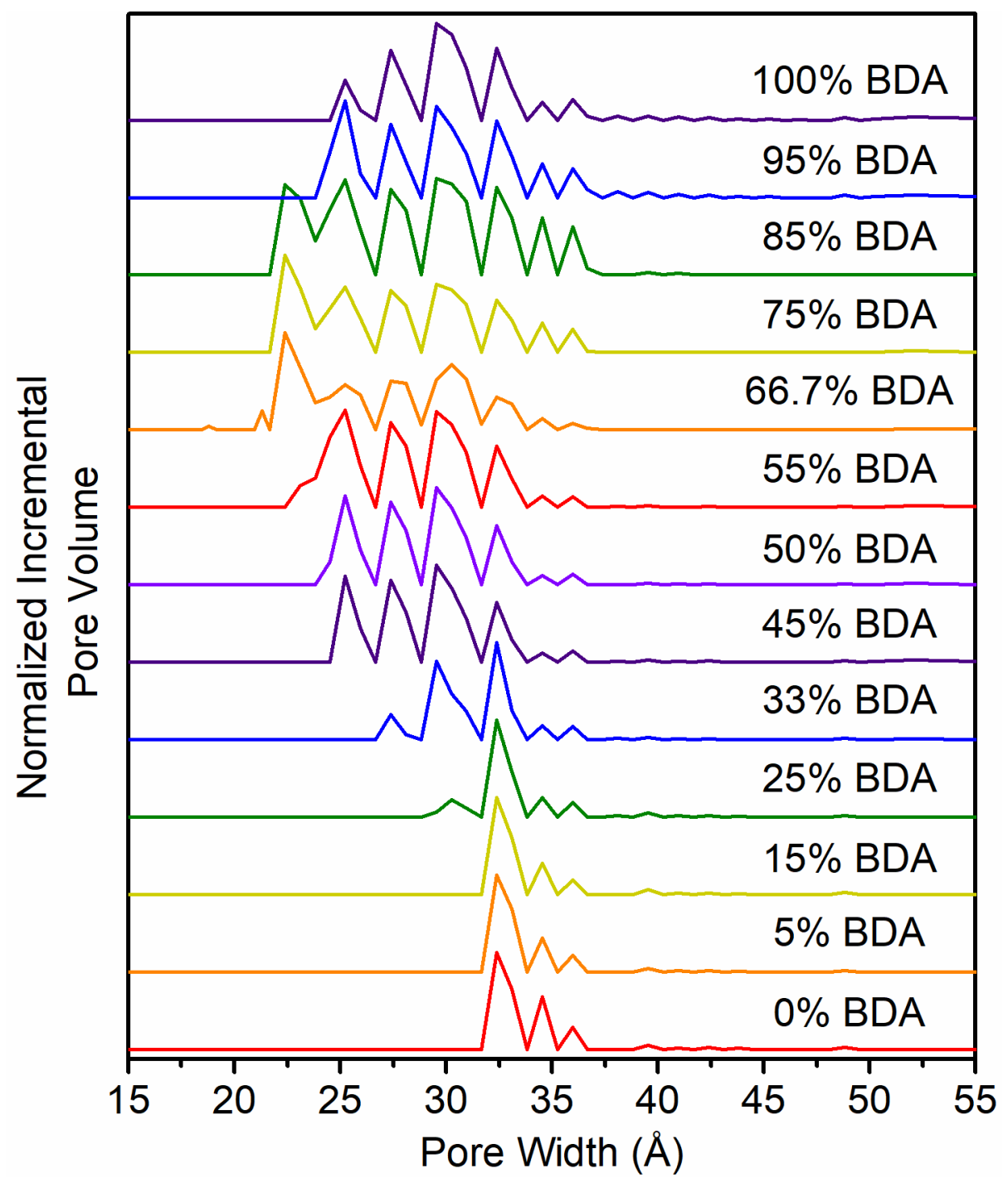

Figure S18. Pore width distribution of TAPB-(PDA $\left.100-\mathrm{BDA} \mathrm{A}_{\mathrm{x}}\right) \mathrm{COF}$ solid solutions synthesized with varying percentages of BDA and PDA linkers. 

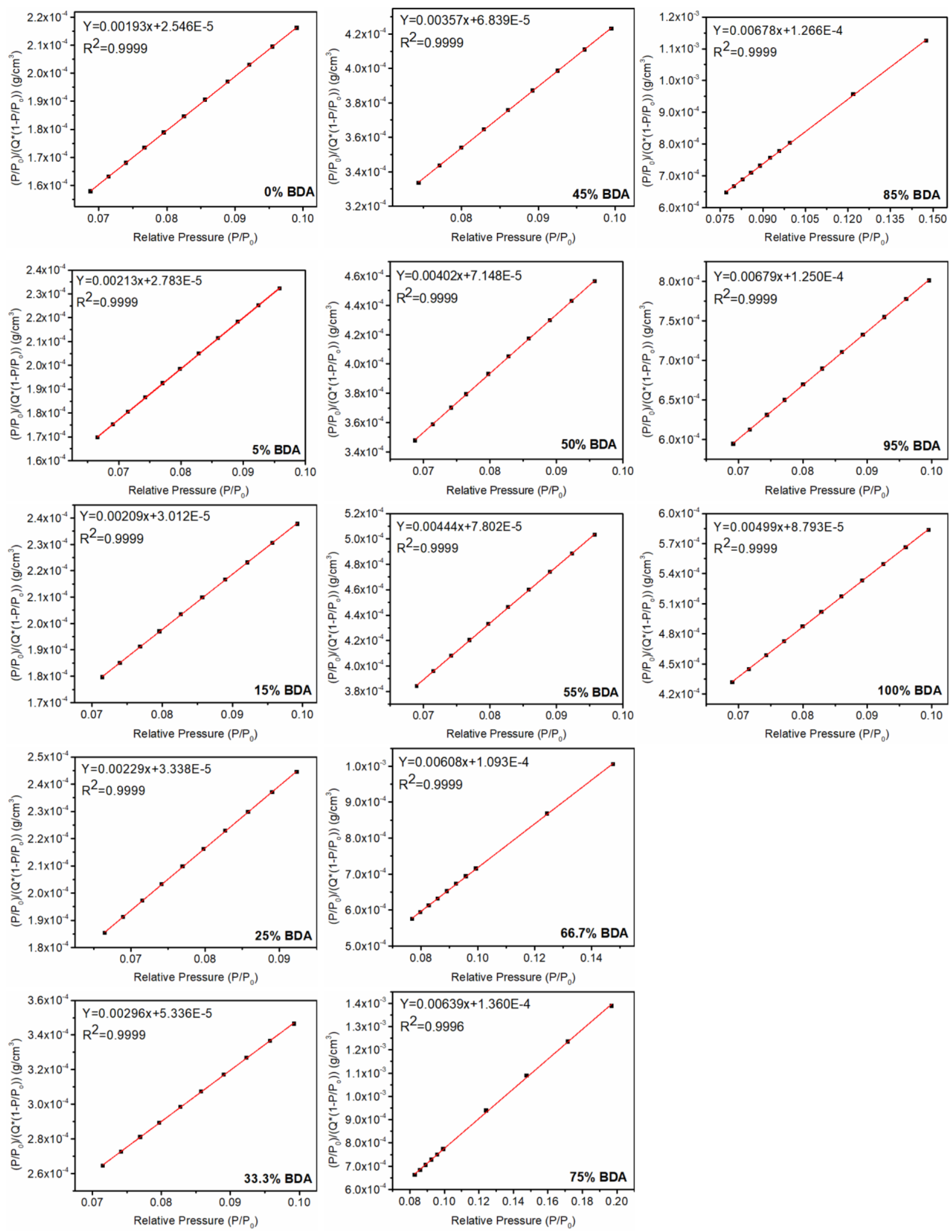

Figure S19. BET plots for TAPB-(PDA $\left.100-\mathrm{BDA} \mathrm{B}_{\mathrm{x}}\right) \mathrm{COF}$ solid solutions synthesized with varying percentages of BDA and PDA linkers. 

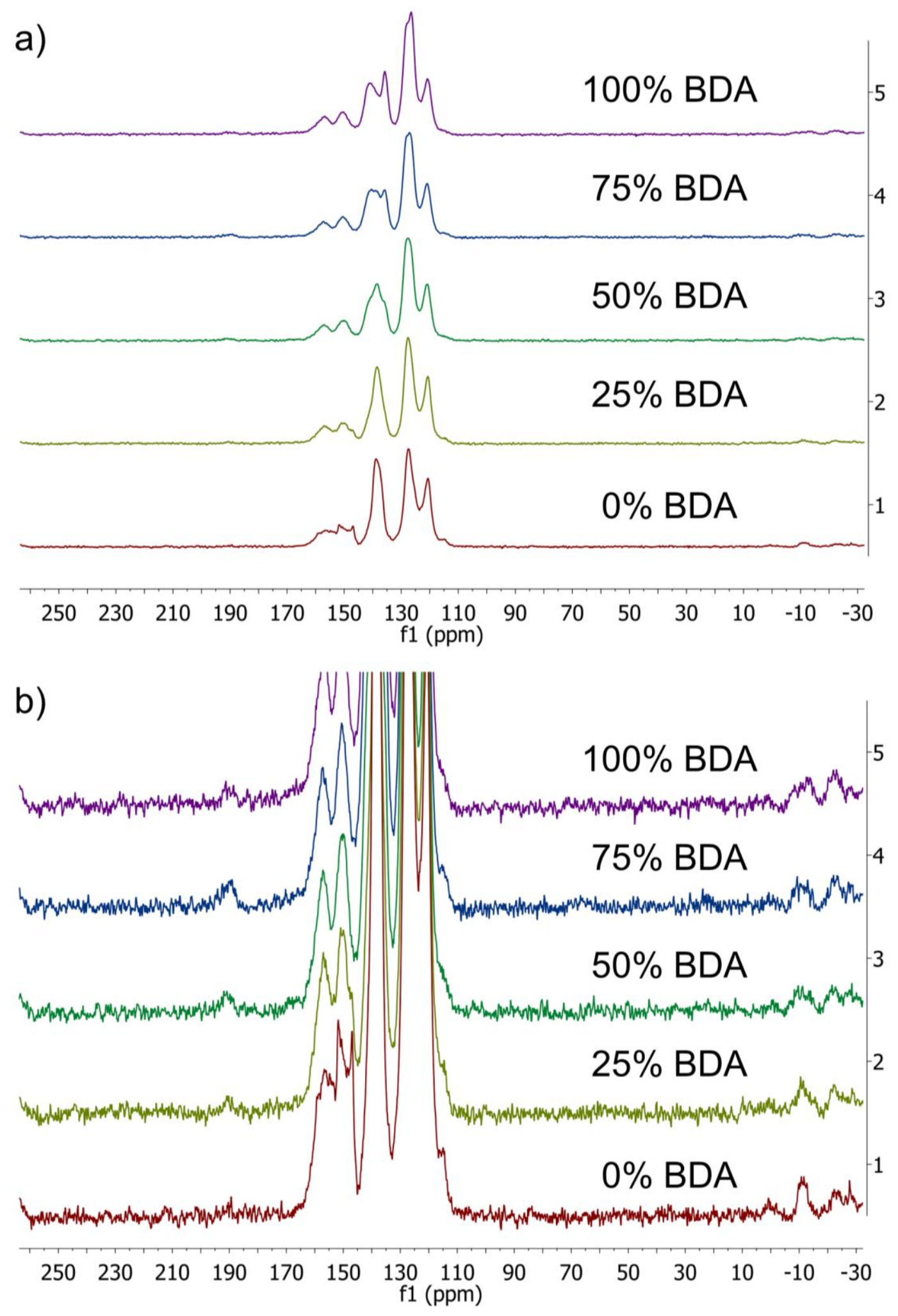

Figure S20. a) CP-MAS ${ }^{13} \mathrm{C}$ NMR spectra $(100 \mathrm{MHz}$, spin rate of $15 \mathrm{kHz})$ of TAPB-(PDA $100-$ $\left.{ }_{x} B A_{x}\right) C O F$ solid solutions. b) Expansion of the peak intensity of the spectra to show peaks near the signal-to-noise threshold. 


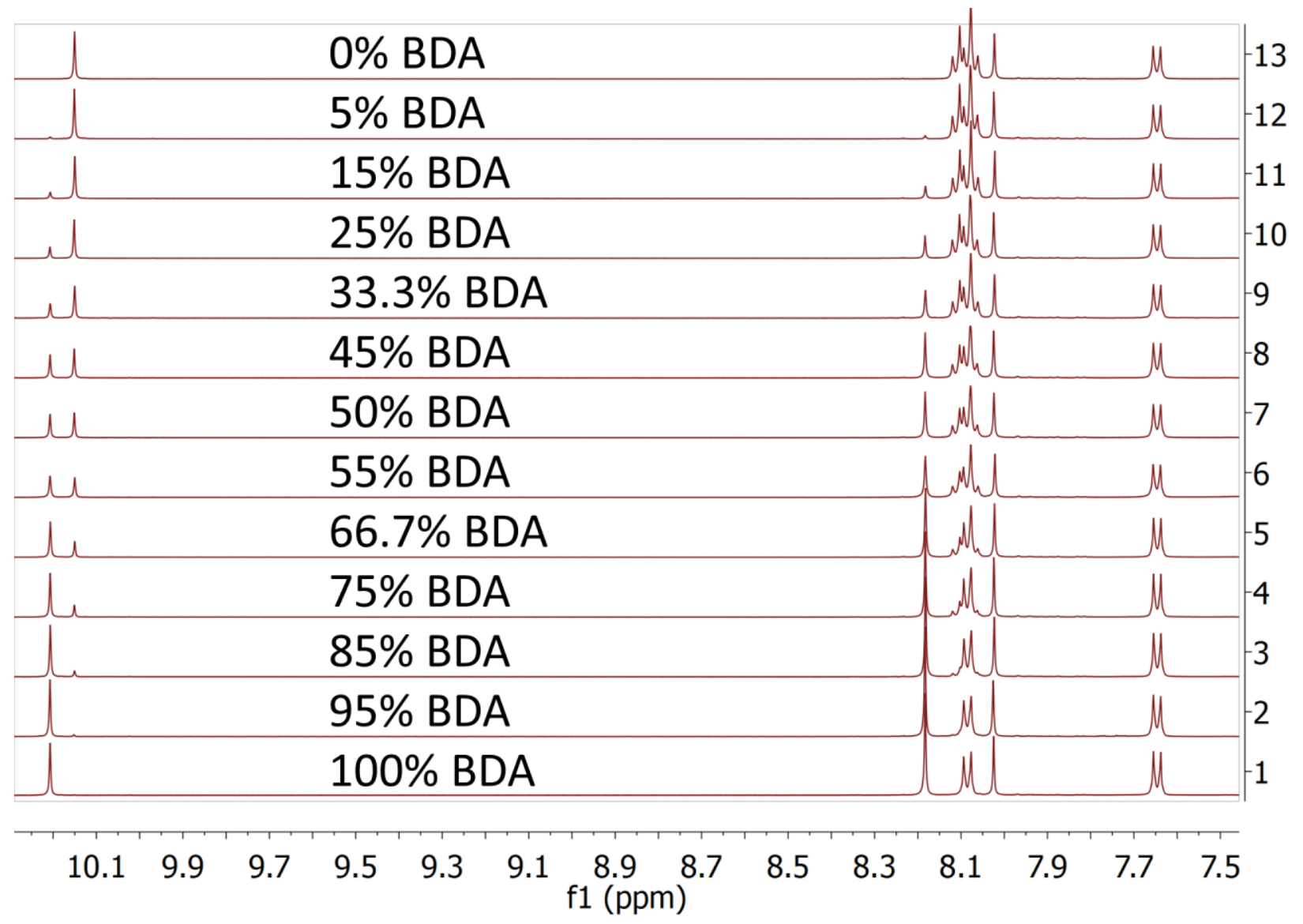

Figure S21. Partial ${ }^{1} \mathrm{H}$ NMR spectra $\left(\mathrm{DMSO}-d_{6}, 500 \mathrm{MHz}, 298 \mathrm{~K}\right)$ of digested TAPB-(PDA $100-$ ${ }_{x} \mathrm{BDA}_{\mathrm{x}}$ ) COF solid solutions. Each COF sample was digested in $\mathrm{DCl}$ in DMSO at $90{ }^{\circ} \mathrm{C}$ to obtain a homogeneous solution (see methods section). 


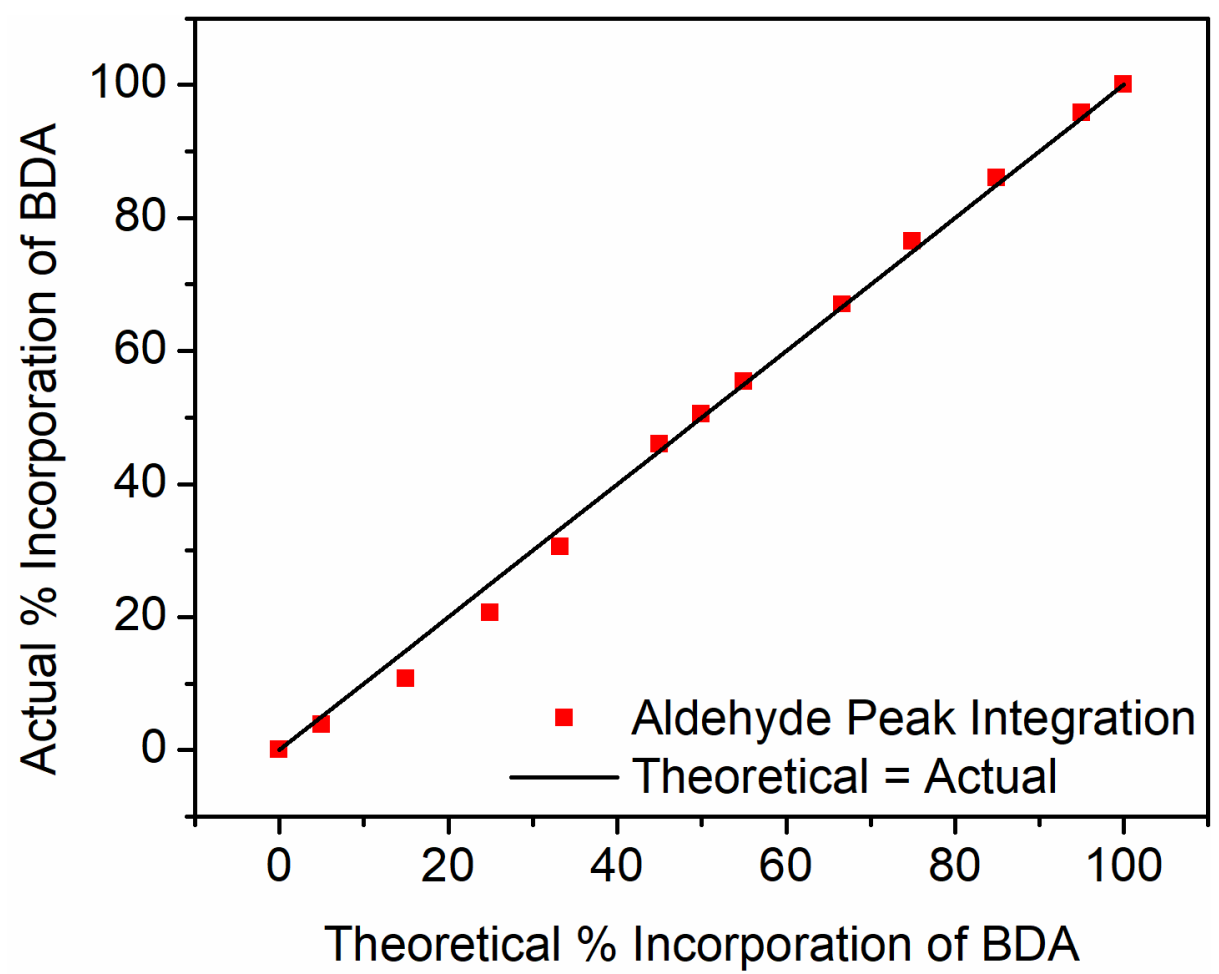

Figure S22. Percentage of BDA incorporated in solid solution samples determined by ${ }^{1} \mathrm{H}$ NMR of digested COF samples compared to the theoretical percentage. Composition analysis was determined from the integration of aldehyde peaks of BDA and PDA in the ${ }^{1} \mathrm{H}$ NMR spectra of digested COF samples. $\mathrm{R}^{2}=99.8 \%$. 


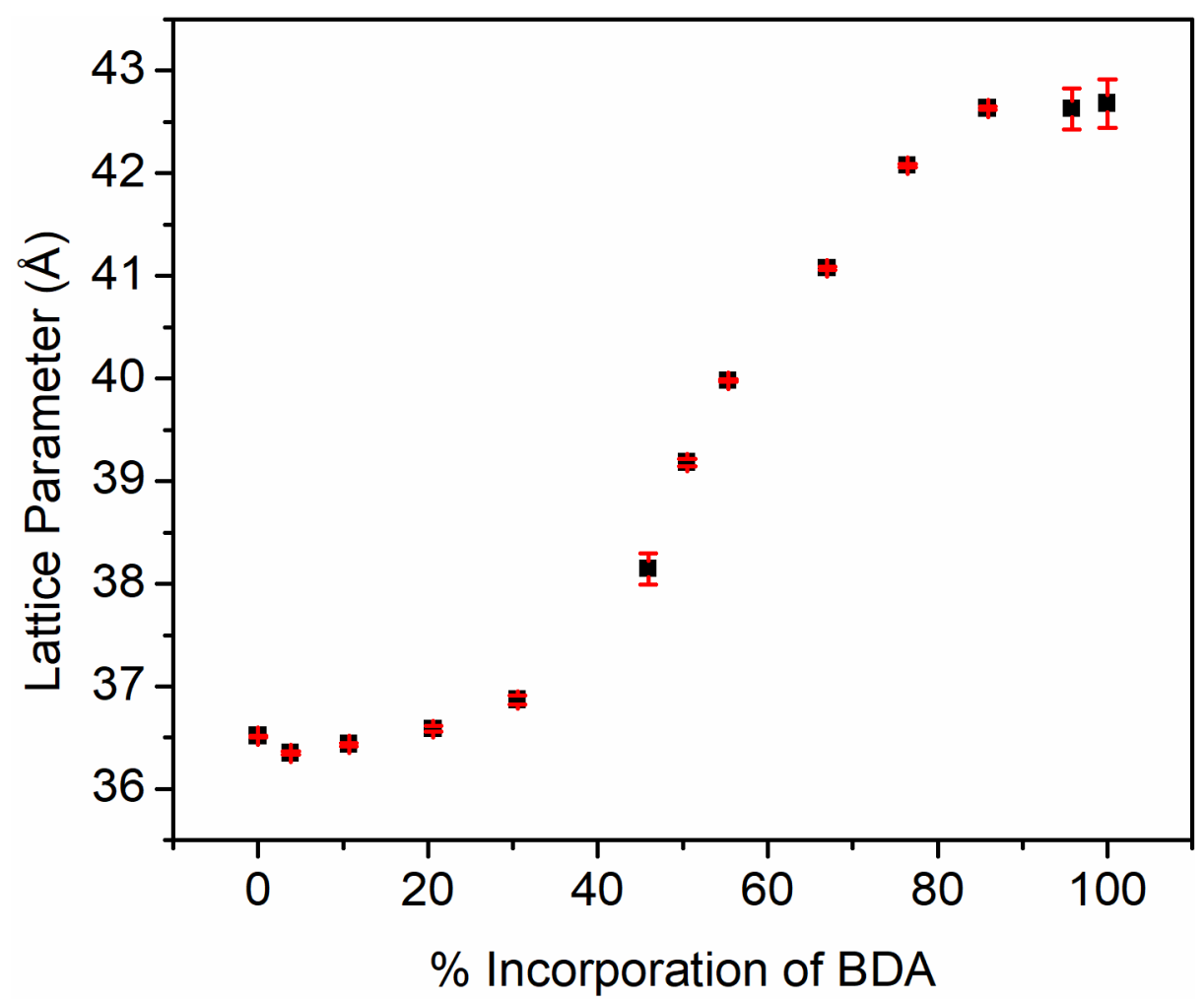

Figure S23. Lattice parameter of the (110) diffraction peak as a function of the percent incorporation of BDA.

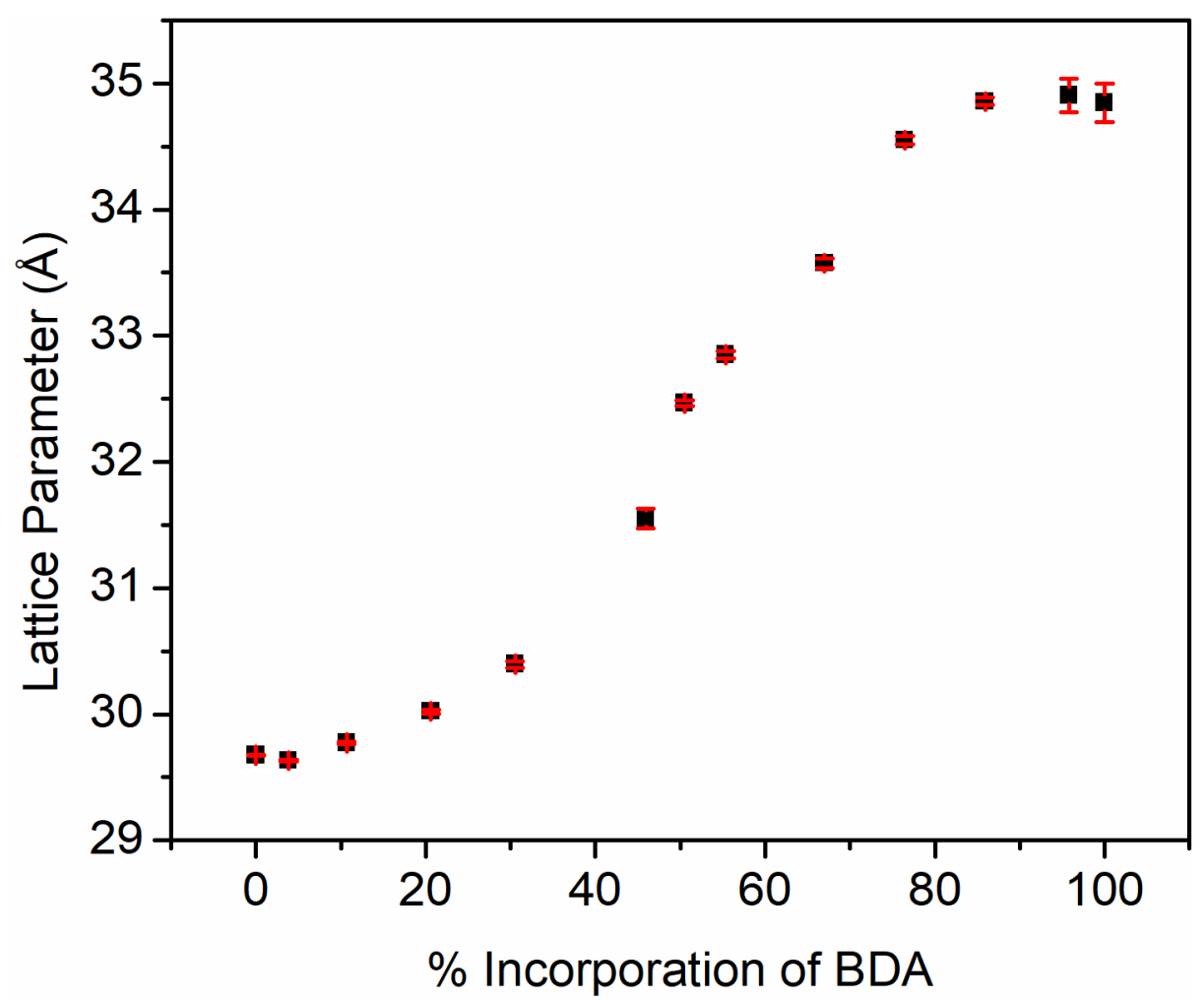

Figure S24. Lattice parameter of the (200) diffraction peak as a function of percent incorporation of BDA. 